\title{
ЕКОБІОМОРФОЛОГІЧНІ ОСОБЛИВОСТІ ПРЕДСТАВНИКІВ РОДУ UTRICULARIA L. В УМОВАХ IНTРОДУКЦIї
}

\author{
Дідух А. Я., Нужина Н. В., Мазур Т. П.
}

\section{ВСТУП}

Україна завдяки своєму географічному положенню ще зберігає надзвичайно багату біоту та належить до країн із великою різноманітністю флори, яка складає понад 25 тис. видів. Охорона і раціональне використання рослинних ресурсів для нашої держави має першочергове значення. Ухвалення нормативних документів «Конвенції про біологічне різноманіття» у Ріо-де-Женейро, з питань охорони довкілля на європейському рівні, спрямувало реалізацію положень Всеєвропейської стратегії збереження біологічного і ландшафтного різноманіття. На державному рівні, 3 ухваленням Закону України «Про загальнодержавну програму формування національної екомережі України» вирішення завдань охорони водної флори і рослинності отримало нові стимули. Згідно із цими основними програмами, долини річок виступатимуть природними екокоридорами міжнародного, національного і регіонального рівнів. Гирлові області великих річок, системи флювіогляціональних і карстових озер, зокрема Українського Полісся, а також надзаплавних озер Лісостепу природними ядрами. Відповідно до «Конвенції про охорону дикої флори і фауни та природних середовищ існування в Європі» ${ }^{1}$ та інших документів, на території України проводяться дослідження фіторізноманіття, зокрема водойм. В Україні потребують охорони більше 600 видів рослин. Особливо актуальною є робота 3 окремими видами рослинності, що занесені до Червоної книги України, таким чином, щоб розробити для кожного з них необхідний комплекс заходів iз метою їх охорони, збереження та можливого практичного використання в умовах інтродукції. Одним із найважливіших завдань Ботанічних садів у наш час $\epsilon$ збереження генофонду рідкісних та зникаючих рослин шляхом інтродукції. Створення колекцій водних, прибережно-водних та комахоїдних рослин в умовах захищеного та відкритого грунту можна розглядати як одну з форм охорони водноболотної флори та збереження іï біорізноманіття - частину загальної стратегії охорони рослин, спрямованої на збереження існування виду

${ }^{1}$ Національна доповідь України про збереження біологічного різноманіття / уклад. В. Давидок та ін. ; за ред. Я. Мовчана, Ю. Шеляг-Сосонко. Київ : Мінекобезпеки України, 1997. 202 с. 
у природі ${ }^{1}$. У сучасних умовах антропогенного впливу природні місцезростання багатьох водних, прибережно-водних і комахоїдних рослин зазнають суттєвої трансформації. Це, у свою чергу, призводить до скорочення чисельності та навіть зникнення окремих локальних популяцій. До таких видів, що перебувають на межі зникнення, належить рід Utricularia L. ${ }^{2}$, який потребує особливого ставлення та вивчення. Родина Lentibulariaceae Rich. має 4 роди (Genlisea A. St-Hil., Pinguicula L., Polypompholy (Lehm.) P. Taylor, Utricularia L.) та більше 250 видів. Рід Utricularia найбільший за кількістю видів серед всіх комахоїдних рослин та налічує 230-250 видів ${ }^{3}$.

У 1989 р. Пітер Тейлор (Taylor Peter. The genus Utricularia : A taxonomic monograph) скоротив кількість видів до 214. Сучасні молекулярно-генетичні дослідження підтвердили погляди П. Тейлора, але рід поділився на три підродини (Biovularia Kamieñski, Polypompholyx та Utricularia) та 34 секціï.

\section{1. Екологічні особливості роду Utricularia L.}

Об'єктом дослідження був рід Utricularia. Комплексний підхід, інтродукційне прогнозування, фенологічні спостереження та лабораторні дослідження проводились на інтродукованих у захищений та відкритий грунт 7 видах роду: Utricularia australis $\mathrm{R}$. Br., U. gibba L., $U$. livida E. Mey., U. minor L., U. prehensilis E. Mey., U. tricolor A. St.-Hil., U. vulgaris L. на базі колекції водних, прибережно-водних i комахоїдних рослин Ботанічного саду ім. акад. О.В. Фоміна. Види колекції визначались за Е. Земськовою ${ }^{5}$, А. Кернер фон Марілаун ${ }^{6}$, W. Goebel $^{7}$, A. Wagner ${ }^{8}$, P. Taylor ${ }^{9}$, а також електронним ресурсом ${ }^{10}$. Систематичний аналіз і правильність написання прізвищ авторів

2 Андрієнко Т. Комахоїдні рослини України / за ред. В. Протопопової. Київ : Альтерпрес, $2010.80 \mathrm{c}$.

3 Земскова Е. Семейство Пузырчатковые (Lentibulariacea). Жизнь растений. Т. 5. Ч. 2. Москва : Просвещение, 1981. С. 440-442.

${ }^{4}$ Taylor P. The genus Utricularia: A taxonomic monograph. Kew Bulletin Additional. Series XIV. London, 1989.720 p.

5 Земскова Е. Семейство Пузырчатковые (Lentibulariacea). Жизнь растений. Т. 5. Ч. 2. Москва : Просвещение, 1981. С. 440-442.

Кернер фон Марилаун А. Жизнь растений. Санкт-Петербург : Книгоиздательское товарищество «Просвещение», 1899. Т. 1. С. 115-145.

${ }^{7}$ Goebel W. Insektivores Pflanzenbiologische Schilderungen. II-ter Teil. Marburg :

N.C. Elwert'sche Verlagsbuchhandlung, 1891. S. 51-174.

Wagner A. Die fleischiressenden Pflanzen. Aus Natur- und Geisteswelt. 344. Leipzig, $1911.128 \mathrm{p}$.

9 Taylor P. The genus Utricularia : A taxonomic monograph. Kew Bulletin Additional. Series XIV. London, 1989. 720 p.

URL: http:// en.wikipedia.org/wiki/ Utricularia ; URL: http://www.omnisterra.com/bot/cp_home.cgi. 
перевіряли за R. Brummitt ${ }^{11}$. Характеристику кліматичних умов місць природного поширення складено на основі літературних першоджерел: А. Тахтаджяна ${ }^{12}$, А. Кернер фон Марілаун ${ }^{13}$, W. Goebel ${ }^{14}$, A. Wagner ${ }^{15}$. Фотографії зроблені за допомогою цифрової камери Canon Power Shot А630. Ареали родини та родів наведені за електронним ресурсом ${ }^{16}$. Екобіоморфу видів визначали за S. Нејný' ${ }^{17}$. Тип пасток встановлювали за М. Холодним ${ }^{18}$, W. Goebel ${ }^{19}$, P. Taylor ${ }^{20}$. Список видів роду Utricularia опрацьовано та наведено за електронним ресурсом ${ }^{21}$.

Представники цієї родини поширені в усіх частинах світу. Більшість iз них трапляються у країнах із тропічним кліматом, у вологих місцях, на болотах, над водоймами, у лісах східної частини тропічної Південної Америки, північної частини Центральної Африки, а також у ПівденноСхідній Азії та тропічній Австралії (рис. 1, табл. 1). Центр видового різноманіття роду Utricularia зосереджений у Південній Америці. Ендемічні та реліктові види зростають в Австралії, Африці, Азії, Індії, Північній Америці та Європі. Раритетні види зосереджені на островах. В Україні до цієї родини належать 4-5 (8) видів ${ }^{22}$. Здебільшого це рідкісні та зникаючі види, які відносяться до комахоїдних рослин ${ }^{23}$. Сучасне систематичне положення родини Lentibulariaceae опрацьовано на основі аналізу й порівняння восьми систем різних авторів, що

${ }^{11}$ Brummitt R. Vascular plant families and genera. London : R.B.G. Kew, 1992. 732 p. ; Brummitt R. Autohors of Plant Names. London : R.B.G. Kew, 1992. 804 p.

Тахтаджян А. Флористические области Земли. Ленинград, 1978. 247 с.

13 Кернер фон Марилаун А. Жизнь растений. Санкт-Петербург : Книгоиздательское товарищество «Просвещение», 1899, Т. 1. С. 115-145.

${ }^{14}$ Goebel W. Insektivores. Pflanzenbiologische Schilderungen. II-ter Teil. Marburg : N.C. Elwert'sche Verlagsbuchhandlung, 1891. S. 51-174.

is Wagner A. Die fleischiressenden Pflanzen. Aus Natur- und Geisteswelt. 344. Leipzig, 1911. $128 \mathrm{p}$.

16 URL: http://en.wikipedia.org/wiki/ Utricularia ; URL: http://www.omnisterra.com/ bot/cp_home.cgi.

Hejný S. Okologische charakteristik der Wasser und Sumpflanzen in den slowakischen Tiefebenen. Bratislava : Vyd-vo SAV, 1960. 487 S.

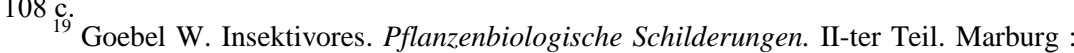
N.C. Elwert'sche Verlagsbuchhandlung, 1891. S. 51-174.

20 Taylor P. The genus Utricularia : A taxonomic monograph. Kew Bulletin Additional. Series XIV. London, 1989. 720 p.

${ }_{21}^{21}$ URL: http://www.omnisterra.com/bot/cp_home.cgi.

22 Андрієнко Т. Комахоїдні рослини України / за ред. В. Протопопової. Київ : Альтерпрес, 2010. 80 с. ; Земскова Е. Семейство Пузырчатковые (Lentibulariacea). Жизнь растений. Т. 5. Ч. 2. Москва : Просвещение, 1981. С. 440-442.

${ }_{23}$ Андрієнко Т. Комахоїдні рослини України / за ред. В. Протопопової. Київ : Альтерпрес, 2010. 80 с.; Земскова Е. Семейство Пузырчатковые (Lentibulariacea). Жизнь растений. Т. 5. Ч. 2. Москва : Просвещение, 1981. С. 440-442 ; Кернер фон Марилаун А. Жизнь растений. Санкт-Петербург : Книгоиздательское товарищество «Просвещение», 1899. Т. 1. С. 115-145. 
належать R. Brummitt ${ }^{24}$. За представленими системами представники родини входять до класу Dicotyledones із різною кількістю видів. Нижче наводимо вісім систем і положення в них родини.

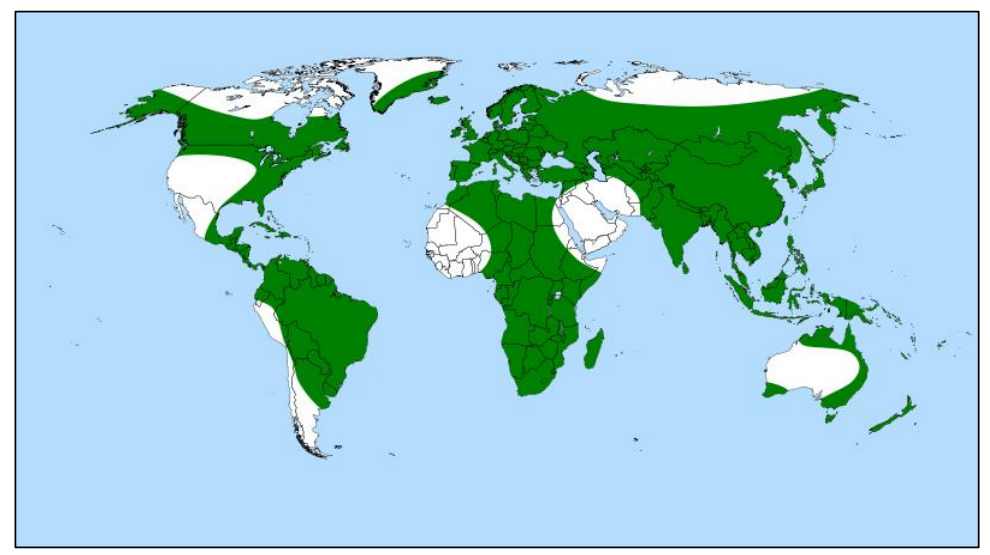

\section{Рис. 1. Ареал роду Utricularia L. (за P. Taylor)}

Lentibulariaceae Rich. 1808

3 genera. Widespread. Insectivorous herbs, some aquatic.

\begin{tabular}{|c|c|c|}
\hline $\mathrm{B} \& \mathrm{H}$ & GAMOPETALAE, & Personales, 117 \\
\hline & BICARPELLATAE & \\
\hline DT\&H & METACHLAMYDEAE & $\begin{array}{l}\text { Tubiflorae, } \\
217\end{array}$ \\
\hline Melc & SYMPETALAE & $\begin{array}{l}\text { Tubiflorae, Solanineae, } \\
275\end{array}$ \\
\hline Thor & GENTIANIFLORAE & Bignoniales, 262 \\
\hline Dahl & LAMIIFLORAE & Scrophulariales, 358 \\
\hline Young & ROSIDAE, GENTIANANAE & Bignoniales, 360 \\
\hline Takh & LAMIIDAE, LAMIANAE & Scrophulariales, 406 \\
\hline Cron & ASTERIDAE & Scrophulariales, 303 \\
\hline
\end{tabular}

Genlisea A. St.-Hil.; Pinguicula L.; Utricularia L. $732 \mathrm{p}$

${ }^{24}$ Brummitt R. Vascular plant families and genera. London : R.B.G. Kew, 1992. 
Список видів роду Utricularia $\mathrm{L}$. залежно від екобіологічних особливостей

\begin{tabular}{|c|c|c|}
\hline Назва виду та поширення & $\begin{array}{c}\text { Рік } \\
\text { відкриття }\end{array}$ & $\begin{array}{l}\text { Екобіоморфологі } \\
\text { чні особливості }\end{array}$ \\
\hline U. adpressa Salzm. ex St. Hil. \& Gir. Ц., Пд. Америка & 1838 & $\mathrm{Bp}, \mathrm{T}$ \\
\hline U. albiflora $\mathrm{R}$. Вr., ендемік Австралії & 1810 & $\mathrm{~T}$ \\
\hline U. albocaerulea Dalz., ендемік Індії & 1851 & $\mathrm{~T}$ \\
\hline U. alpina Јасq., Пд. Америка & 1760 & $\mathrm{~T}, \mathrm{E}$ \\
\hline U. amethystina Salzm. ex St. Hil. \& Gir., Флорида & 1838 & $\mathrm{~T}$ \\
\hline U. andongensis Welw. ex Hiern., Флорида & 1900 & $\mathrm{~T}$, Л \\
\hline U. antennifera P. Taylor, Сх. Австралія & 1986 & $\mathrm{~T}$ \\
\hline U. appendiculata E. A. Bruce, ендемік Африки & 1934 & $\mathrm{~T}$ \\
\hline U. arcuata $\mathrm{R}$. Wight, ендемік Індії & 1849 & $\mathrm{~T}$ \\
\hline U. arenaria А. DC., Пд. Африка & 1844 & $\mathrm{~T}$ \\
\hline U. arnhemica P. Taylor, ендемік Австралії & 1986 & $\mathrm{Bp}, \mathrm{T}$ \\
\hline U. asplundii Р. Taylor, ендемік сх. частини Пд. Америки & 1975 & $\mathrm{~T}, \mathrm{E}$ \\
\hline U. aurea Lour., Індія, Японія, Австралія & 1790 & Впр \\
\hline U. aureomaculata Steyerm., ендемік Венесуели & 1953 & Л \\
\hline $\begin{array}{l}\text { U. australis R. Br., Свропа, Азія, Китай, Японія, } \\
\text { Австралія }\end{array}$ & 1810 & Впр \\
\hline U. babui Yadav, Sardesai \& Gaikwad, Індія & 2005 & $\mathrm{~T}$ \\
\hline U. beaugleholei Gassin, Австралія & 1993 & $\mathrm{~T}$ \\
\hline U. benjaminiana Oliv., Африка, Ц. та Пд. Америка & 1860 & Нзпр \\
\hline U. benthamii P. Taylor, Сх. Австралія & 1986 & $\mathrm{~T}$ \\
\hline $\begin{array}{l}\text { U. bifida L., Азія, Океанія, Австралія, Китай, Індія, п-ів } \\
\text { Індонезія, Японія, п-ів Корея, Лаос, Малайзія, Непал, } \\
\text { о. Нова Гвінея, Філіппінські острови, о. Шрі-Ланка, } \\
\text { Таїланд, В’єтнам }\end{array}$ & 1753 & $\mathrm{~T}$ \\
\hline U. biloba R. Вr., ендемік Австралії & 1810 & Пр, T \\
\hline $\begin{array}{l}\text { U. biovularioides (Kuhlm.) P. Taylor } \\
\text { (Bas.: Saccolaria biovularioides), Бразилія }\end{array}$ & 1986 & Впр \\
\hline U. bisquamata Schrank, Пд. Африка & 1824 & $\mathrm{~T}$ \\
\hline U. blackmanii R. W. Jobson, Австралія & 2012 & $\mathrm{~T}$ \\
\hline U. blanchetii A. DC., ендемік Бразилії & 1844 & $\mathrm{~T}, \pi$ \\
\hline U. bosminifera Ostenf., ендемік Таїланду & 1906 & Пр \\
\hline $\begin{array}{l}\text { U. brachiata (R Wight) Oliv., від східних Гімалаїв до } \\
\text { Юньнаня }\end{array}$ & 1859 & Л \\
\hline U. bracteata Good, ендемік Пд., Троп. Африки & 1924 & $\mathrm{~T}$ \\
\hline U. bremii Heer, Ц. та Зх. Свропа & 1830 & Нзпр \\
\hline U. breviscapa Wright ex Griseb., Пд. Америка & 1866 & Впр \\
\hline U. buntingiana P. Taylor, ендемік Венесуели & 1975 & $\mathrm{E}$ \\
\hline $\begin{array}{l}\text { U. caerulea L., Японія, Китай, Корейський півострів, Пд. } \\
\text { Азія, Пд. Африка (о. Мадагаскар), Пн.-Сх. Австралія, о. } \\
\text { Шрі-Ланка, Уссурійськ }\end{array}$ & 1753 & $\mathrm{~T}$ \\
\hline $\begin{array}{l}\text { U. calycifida Benj., ендемік пн. частини Пд. Америки, } \\
\text { Бразилія, Гуйяна, Венесуела }\end{array}$ & 1847 & $\mathrm{~T}$ \\
\hline $\begin{array}{l}\text { U. campbelliana Oliv., ендемік пн. частини Пд. Америки } \\
\text { (Бразилія, Гуйяна та Венесуела) }\end{array}$ & 1887 & $\mathrm{E}$ \\
\hline
\end{tabular}


Продовження таблиці 1

\begin{tabular}{|c|c|c|}
\hline Назва виду та поширення & \begin{tabular}{c|c|} 
Рік \\
відкриття \\
\end{tabular} & $\begin{array}{c}\text { Екобіоморфологі } \\
\text { чні особливості }\end{array}$ \\
\hline U. capilliflora F. Muell., Австралія & 1890 & $\mathrm{~T}$ \\
\hline U. cecilii P. Taylor, Індія & 1984 & $\mathrm{~T}$ \\
\hline U. cheiranthos P. Taylor, Австралія & 1986 & $\mathrm{~T}$ \\
\hline U. chiakiana Komiya \& Shibata, Венесуела & 1997 & $\mathrm{Bp}$ \\
\hline $\begin{array}{l}\text { U. chiribiquitensis Fernandez-Perez, ендемік Колумбіï } \\
\text { та Венесуели }\end{array}$ & 1964 & $\mathrm{~T}$ \\
\hline $\begin{array}{l}\text { U. choristotheca P. Taylor, ендемік пн. частини } \\
\text { Пд. Америки }\end{array}$ & 1986 & $P$ \\
\hline U. christopheri P. Taylor, Азія, Непал, Індія & 1986 & Л \\
\hline $\begin{array}{l}\text { U. chrysantha R. Вr., ендемік Австралії, пд. частини о. } \\
\text { Нова Гвінея }\end{array}$ & 1810 & $\mathrm{~T}$ \\
\hline U. circumvoluta P. Taylor, Пн. Австралія (Квінсленд) & 1986 & $\mathrm{~T}$ \\
\hline U. cornuta Michx., ендемік Пн. Америки & 1803 & Впр, T \\
\hline U. corynephora P. Taylor, Бірма, Таїланд & 1986 & Л \\
\hline U. costata P. Taylor, ендемік Бразилії, Венесуели & 1986 & Т, Л \\
\hline U. cucullata St. Hil. \& Gir., ендемік Пд. Америки & 1838 & Впр \\
\hline $\begin{array}{l}\text { U. cymbantha Welw. ex Oliv., Ангола, о. Мадагаскар, } \\
\text { Африка, Уганда, Заїр }\end{array}$ & 1865 & Впр \\
\hline U. delicatula Cheesem., ендемік о. Нової Зеландії & 1906 & $\mathrm{~T}$ \\
\hline U. delphinioides Thorel ex Pellegr., ендемік п-ва Індокитай & 1920 & $\mathrm{~T}$ \\
\hline U. determannii P. Taylor, Пд. Америка & 1986 & $\mathrm{P}$ \\
\hline U. dichotoma Labill., Австралія & 1804 & $\mathrm{~T}$ \\
\hline U. dimorphantha Makino, ендемік Японії & 1906 & Впр \\
\hline U. dunlopii P. Taylor, Австралія & 1986 & $\mathrm{~T}$ \\
\hline U. dunstaniae F. E. Lloyd, Пн.-Зх. Австралія & 1936 & $\mathrm{~T}$ \\
\hline $\begin{array}{l}\text { U. endresii Rchb. f., ендемік Ц. Америки та пн.-зх. } \\
\text { частини Пд. Америки }\end{array}$ & 1874 & E \\
\hline U. erectiflora St. Hil. \& Gir., Ц. та Пд. Америка & 1838 & $\mathrm{~T}$ \\
\hline U. fimbriata Н. В. К., Колумбія та Венесуєла & 1818 & $\mathrm{~T}$ \\
\hline U. firmula Welw. Ex Oliv., Троп. та Пд. Африка & 1865 & 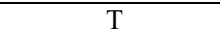 \\
\hline U. fistulosa P. Taylor, пн.-сх. част. Зх. Австралії & 1986 & Нзр \\
\hline $\begin{array}{l}\text { U. flaccida A. DC., ендемік Бразилії } \\
\end{array}$ & 1844 & $\mathrm{~T}$ \\
\hline U. floridana Nash, ендемік Пн.-Сx. Америки & 1896 & Нзр \\
\hline U. foliosa L., Африка, Пн., Пд. Америка & 1753 & Впр \\
\hline U. forrestii P. Taylor, Пн. Бірма, Зх. Китай & 1986 & Л \\
\hline $\begin{array}{l}\text { U. foveolata Edgew. Тропіки Старого Світу, Африка, } \\
\text { Азія, Австралія, сх. частина о. Ява }\end{array}$ & 1847 & П, Т \\
\hline U. fulva F. Muell., ендемік Австралії & 1858 & $\Pi, \mathrm{T}$ \\
\hline U. furcellata Oliv., ендемік Пн.-Сх. Індії & 1859 & Л \\
\hline U. garrettii P. Taylor, Таїланд & 1986 & л \\
\hline U. geminiloba Benj., Бразилія & 1847 & Т, Л \\
\hline U. geminiscapa Benj., Пн.-Сx. Америка, Пн.-Сх. Канада & 1847 & Впр \\
\hline U. geoffrayi Pellegr., п-ів Індокитай & 1920 & $\mathrm{~T}$ \\
\hline U. georgei P. Taylor, Зх. Австралія, Африка & 1986 & $\mathrm{~T}$ \\
\hline U. gibba L., Австралія, Африка, Пд.-Сх. Азія & 1753 & Нзпр \\
\hline U. graminifolia Vahl, п-ів Індокитай & 1804 & $\Pi, \mathrm{T}, \mathrm{E}$ \\
\hline U. guyanensis А. DC., Ц. та Пд. Америка & 1844 & $\mathrm{~T}$ \\
\hline
\end{tabular}


Продовження таблиці 1

\begin{tabular}{|c|c|c|}
\hline Назва виду та поширення & \begin{tabular}{|c|} 
Рік \\
відкриття
\end{tabular} & $\begin{array}{l}\text { Екобіоморфологі } \\
\text { чні особливості }\end{array}$ \\
\hline U. hamiltonii F. E. Lloyd, ендемік Пн. Австралії & 1936 & Нзр \\
\hline U. helix P. Taylor, Зх. Австралія & 1986 & Нзр \\
\hline U. heterochroma Steyerm., Венесуела & 1953 & $\mathrm{P}$ \\
\hline $\begin{array}{l}\text { U. heterosepala Benj., ендемік Філіппінських островів } \\
\text { (острови Палау, Лузон і Сібуян) }\end{array}$ & 1847 & $\Pi$ \\
\hline U. hintonii Р. Taylor, ендемік Мексики & 1986 & Л \\
\hline $\begin{array}{l}\text { U. hirta Klein ex Link, Індія, Південно-Сx. Азія: Лаос, } \\
\text { Бангладеш, Камбоджа, В’єтнам, острови Шрі-Ланка, } \\
\text { Таїланд, Борнео }\end{array}$ & 1820 & $\mathrm{~T}$ \\
\hline U. hispida Lam., ендемік Цнт. та Пд. Америки & 1791 & $\Pi p, T$ \\
\hline U. holtzei F. Muell., Австралія & 1893 & Bp \\
\hline $\begin{array}{l}\text { U. humboldtii Schomb., ендемік Пд. } \\
\text { Америки (Бразилія, Гуйяна, Венесуела) }\end{array}$ & 1841 & $\Pi p, T$, E \\
\hline U. huntii P. Taylor, ендемік Бразилії & 1986 & $\mathrm{~T}$ \\
\hline U. hydrocarpa Vahl, тропіки Пн. та Пд. Америки & 1804 & Впр \\
\hline U. inaequalis A. DC., Пд.-Зх. Австралія & 1844 & $\mathrm{~T}$ \\
\hline U. nflat (A. Rich.) Alain, (Bas.: Drosera incisa), о. Куба & 1956 & Впр \\
\hline U. inflata Walt., Пн.-Сх. Америки & 1788 & Впр \\
\hline U. inflexa Forsk., Тропічна Африка, о. Мадагаскар, Індія & 1775 & Впр \\
\hline $\begin{array}{l}\text { U. intermedia Hayne, Пн. Америка, Азія, Свропа } \\
\end{array}$ & 1800 & Нзр \\
\hline U. inthanonensis Suksathan \& J.Parn., Таїланд & 2010 & $\mathrm{E}$ \\
\hline $\begin{array}{l}\text { U. involvens Ridl., Південно-Сх. Азія, Бірма, Малайзія, } \\
\text { Таїланд, Пн.-Сх. Австралія }\end{array}$ & 1895 & $\mathrm{~T}$ \\
\hline U. jackii J. Parn., ендемік Таїланду & 2005 & $\mathrm{~T}$ \\
\hline $\begin{array}{l}\text { U. jamesoniana Oliv., Ц. Америка та пн.-захід Пд. } \\
\text { Америки }\end{array}$ & 1860 & E \\
\hline $\begin{array}{l}\text { U. juncea } \text { Vahl, Ц., Пд. та Пн. Америка } \\
\end{array}$ & 1804 & $\mathrm{~T}$ \\
\hline U. kamienskii F. Muell., Австралія & 1893 & $\mathrm{~T}$ \\
\hline U. kenneallyi P. Taylor, ендемік 3х. Австралії & 1986 & $\mathrm{~T}$ \\
\hline U. kimberleyensis C. А. Gardn., Австралія & 1930 & $\mathrm{~T}$ \\
\hline U. kumaonensis Oliv., Індія, Непал, Китай & 1859 & $\mathrm{~T}, \mathrm{E}$, Л \\
\hline U. laciniata St. Hil. \& Gir., Бразилія & 1838 & $\mathrm{~T}$ \\
\hline U. lasiocaulis F. Muell., Австралія & 1885 & $\mathrm{~T}$ \\
\hline U. lateriflora R. Вr. Австралія & 1810 & $\mathrm{~T}$ \\
\hline U. laxa St. Hil. \& Gir. Аргентина, Парагвай, Бразилія & 1838 & $\mathrm{~T}$ \\
\hline U. lazulina P. Taylor, Індія & 1984 & $\mathrm{~T}$ \\
\hline U. leptoplectra F. Muell., Австралія & 1885 & Пр, T \\
\hline U. leptorhyncha Schwarz, Австралія & 1927 & $\mathrm{~T}$ \\
\hline U. letestui P. Taylor, ендемік ПАР & 1989 & $\mathrm{~T}$ \\
\hline \begin{tabular}{|l|} 
U. limosa R. Вr., ендемік Австралії, Пд.-Сх. Азії (Лаос, \\
Китай, Малайзія, острови Нова Гвінея, Таїланд, В’єтнам)
\end{tabular} & 1810 & $\Pi p, \mathrm{~T}$ \\
\hline $\begin{array}{l}\text { U. livida Е. Меу., Ефіопія, Капська провінція, } \\
\text { o. Мадагаскар, Мексика }\end{array}$ & 1837 & $\mathrm{~T}$ \\
\hline U. lloydii Merl ex F. E. Lloyd, Ц. та Пд. Америка & 1932 & $\mathrm{~T}$ \\
\hline U. longeciliata А. DC., ендемік Пд. Америки & 1844 & $\mathrm{~T}$ \\
\hline U. longifolia Gardn., ендемік Бразилії & 1842 & Т, Л \\
\hline U. lowriei R. W. Jobson, Австралія (Kв & 2013 & $\Pi$ Пр. T \\
\hline
\end{tabular}


Продовжен

\begin{tabular}{|c|c|c|}
\hline Назва виду та поширення & $\begin{array}{c}\text { Рік } \\
\text { відкриття }\end{array}$ & $\begin{array}{l}\text { Екобіоморфологі } \\
\text { чні особливості }\end{array}$ \\
\hline $\begin{array}{l}\text { U. macrocheilos (P. Taylor) P. Taylor (Bas.: U. micropetala } \\
\text { var. macrocheilos), троп. Африка }\end{array}$ & 1986 & - \\
\hline U. macrorhiza Le Conte, Пн. Америка, Сх. Азія & 1824 & Впр \\
\hline U. malabarica Janarthanam \& Henry, ендемік Пд. Індії & 1989 & Л \\
\hline U. mangshanensis $\mathrm{G} . \mathrm{W}$. Нu, Китай & 2007 & $\mathrm{~T}$ \\
\hline U. mannii Oliv., ендемік Тропічної Африки & 1865 & $\mathrm{E}$ \\
\hline U. menziesii R. Вr., ендемік Зх. Австралії & 1810 & $\mathrm{~T}$ \\
\hline U. meyeri Pilger, Бразилія & 1901 & $\mathrm{~T}$ \\
\hline $\begin{array}{l}\text { U. microcalyx (P. Taylor) P. Taylor (Bas.: U. welwitschii } \\
\text { var. microcalyx), Тропічна Африка }\end{array}$ & 1971 & $\mathrm{~T}$ \\
\hline U. micropetala Sm., ендемік Ц. та Зх. Африки & 1819 & $\mathrm{~T}$ \\
\hline U. minor L., Пн. Америка, Азія, Європа & 1753 & Нзр \\
\hline $\begin{array}{l}\text { U. minutissima Vahl, Азія, Австралія, Японія, о. Нова } \\
\text { Гвінея }\end{array}$ & 1804 & $\mathrm{~T}$ \\
\hline U. mirabilis P. Taylor, Пд. Америка, Венесуела & 1986 & $\mathrm{P}$ \\
\hline $\begin{array}{l}\text { U. monanthos Hook. F., Австралія, Тасманія, о-ви Нової } \\
\text { Зеландії }\end{array}$ & 1860 & $\mathrm{~T}$ \\
\hline U. moniliformis P. Taylor, о. Шрі-Ланка & 1986 & Л \\
\hline U. muelleri Kam., Пн. Австралія, Папуа, о. Нова Гвінея & 1894 & Впр \\
\hline U. multicaulis Oliv., Китай, Індія, Непал & 1859 & Л \\
\hline U. multifida R. Br., Пд.-Зх. Австралія & 1810 & $\mathrm{~T}$ \\
\hline $\begin{array}{l}\text { U. myriocista St. Hil. \& Gir., ендемік Пд. Америки } \\
\text { (Аргентина, Болівія, Бразилія, Гуйяна, Тринідад, } \\
\text { Венесуела) }\end{array}$ & 1838 & Впр \\
\hline $\begin{array}{l}\text { U. nana St. Hil. \& Gir., Пд. Америка (Бразилія, Гуйяна, } \\
\text { Суринам, Венесуела) }\end{array}$ & 1838 & $\mathrm{~T}$ \\
\hline U. naviculata P. Taylor, Бразилія, Венесуела & 1967 & Впр \\
\hline U. nelumbifolia Gardn., ендемік Бразилії & 1852 & $\mathrm{E}$ \\
\hline $\begin{array}{l}\text { U. neottioides St. Hil. \& Gir., Бразилія, Колумбія, } \\
\text { Венесуела }\end{array}$ & 1838 & P \\
\hline U. nephrophylla Benj., ендемік Бразилії & 1847 & Л \\
\hline U. nervosa G. Weber ex Benj., Пд. Америка & 1847 & $\mathrm{~T}$ \\
\hline U. nigrescens Sylven, ендемік Бразилії & 1909 & $\mathrm{~T}$ \\
\hline U. novae-zelandiae Hook. f., о. Нова Зеландія & 1853 & $\mathrm{~T}$ \\
\hline U. ochroleuca Hartm., Європа, Японія, Пн.-Зх. Америка & 1857 & Нзр \\
\hline U. odontosepala Stapf, Тропічна Африка & 1912 & $\mathrm{~T}$ \\
\hline U. odorata Pellegr., Пд. Азія & 1920 & $\mathrm{~T}$ \\
\hline $\begin{array}{l}\text { U. olivacea Wright ex Griseb., схід Пн. Америки, Пд. } \\
\text { Америка }\end{array}$ & 1866 & Впр \\
\hline $\begin{array}{l}\text { U. oliveriana Steyerm., Венесуела, Амазонія, } \\
\text { Колумбія }\end{array}$ & 1953 & $\mathrm{P}$ \\
\hline U. panamensis Steyerm. ex Р. Taylor, Ц. Америка, Панама & 1986 & Л \\
\hline U. parthenopipes $\mathrm{P}$. Taylor, ендемік Бразилії & 1986 & $\mathrm{~T}$ \\
\hline U. paulineae Lowrie, ендемік 3х. Австралії & 1998 & $\mathrm{~T}$ \\
\hline U. pentadactyla $\mathrm{P}$. Taylor, Тропічна Африка & 1954 & $\mathrm{~T}$ \\
\hline U. peranomala P. Taylor, ендемік Китаю & 1986 & Л \\
\hline U. perversa P. Taylor, ендемік Мексики & 1986 & Впр \\
\hline
\end{tabular}


Продовження таблиці 1

\begin{tabular}{|c|c|c|}
\hline Назва виду та поширення & $\begin{array}{c}\text { Рік } \\
\text { відкриття }\end{array}$ & $\begin{array}{c}\text { Екобіоморфологі } \\
\text { чні особливості }\end{array}$ \\
\hline U. petersoniae P. Taylor, ендемік Мексики & 1986 & Л \\
\hline U. petertaylorii Lowrie, Південно-3х. Австралія & 2002 & $\mathrm{~T}$ \\
\hline U. phusoidaoensis Suksathan \& J. Parn., Таїланд & 2010 & Л \\
\hline U. physoceras P. Taylor, ендемік Бразилії & 1986 & $\mathrm{~T}$ \\
\hline $\begin{array}{l}\text { U. pierrei Pellegr., п-ів Індокитай (Таїланд, В’єтнам) } \\
\end{array}$ & 1920 & $\mathrm{~T}$ \\
\hline U. platensis Speg., ендемік Пд. Америки & 1899 & Впр \\
\hline U. pobeguinii Pellegr., ендемік Африки & 1914 & $\mathrm{~T}$ \\
\hline $\begin{array}{l}\text { U. poconensis Fromm-Trinta, ендемік Пд. Америки } \\
\text { (Бразилія, Болівія, Аргентина) }\end{array}$ & 1985 & Впр \\
\hline U. podadena P. Taylor, Африка & 1964 & $\mathrm{~T}$ \\
\hline U. polygaloides Edgew., Індія, Зх. Бенгал, о. Шрі-Ланка & 1847 & $\mathrm{~T}$ \\
\hline $\begin{array}{l}\text { U. praelonga St. Hil. \& Gir. Пд. Америка (Аргентина, } \\
\text { Бразилія, Парагвай) }\end{array}$ & 1838 & $\mathrm{~T}$ \\
\hline U. praeterita P. Taylor, ендемік Індії & 1983 & $\mathrm{~T}$ \\
\hline $\begin{array}{l}\text { U. praetermissa Р. Taylor, ендемік Ц. Америки: Коста- } \\
\text { Ріка, Нікарагуа, Панама }\end{array}$ & 1977 & $\mathrm{E}, \mathrm{T}$ \\
\hline $\begin{array}{l}\text { U. prehensilis Е. Меу., тропічна Африка (Ангола, ПАР, } \\
\text { ДР Конго, Ефіопія, Кенія, о. Мадагаскар), Пд. Африка, } \\
\text { Танзанія, Замбія, Зімбабве }\end{array}$ & 1837 & $\mathrm{~T}$ \\
\hline U. pubescens Sm., Індія, Тропічна Ц., Пд. Африка & 1819 & Т, Л \\
\hline U. pulchra P. Taylor, ендемік о. Нова Гвінея & 1977 & Т, Л \\
\hline $\begin{array}{l}U . \text { punctata Wall. ex A. DC., Борнео, Бірма, Китай, } \\
\text { Малайзія, о. Суматра, В'єтнам, Тайланд }\end{array}$ & 1844 & Впр \\
\hline U. purpurea Wlat., Пн. Америка, Куба, Гондурас & 1788 & Впр \\
\hline U. purpureocaerulea St. Hil. \& Gir., енд. Бразилії & 1838 & $\mathrm{~T}$ \\
\hline $\begin{array}{l}\text { U. pusilla Vahl, Ц., Пд. Америка (Аргентина, Перу, } \\
\text { Болівія, Бразилія, Колумбія, Коста-Ріка, о-ви Куба, } \\
\text { Ямайка, Домінік. Респ., Пуерто-Ріко, Венесуела, } \\
\text { Еквадор, Мехіко, Гуйяна, Гондурас, Нікарагуа, Панама, } \\
\text { Парагвай, Суринам, Тринідад }\end{array}$ & 1804 & $\mathrm{~T}$ \\
\hline U. quelchii N. Е. Вr., ендемік Гуйяна та Венесуели & 1901 & $\mathrm{~T}, \mathrm{E}$ \\
\hline U. quinquedentata F. Muell. ex P. Taylor, Австралія & 1986 & $\mathrm{~T}$ \\
\hline U. radiata Small, Пн. Америка & 1903 & Впр \\
\hline U. raynalii P. Taylor, ендемік тропічної Африки & 1986 & Впр \\
\hline U. recta P. Taylor, Індія Непал, Бутан, Китай & 1986 & $\mathrm{~T}$ \\
\hline U. reflexa Oliv., ендемік Африки, о. Мадагаскар & 1865 & Впр \\
\hline U. regia Zamudio \& Olvera, ендемік Мексики & 2009 & $\pi$ \\
\hline U. reniformis St. Hil., ендемік Бразилії & 1830 & $\Pi p, T, E$ \\
\hline $\begin{array}{l}\text { U. resupinata Greene, Схід Канади, Схід Пн. } \\
\text { Америки, пн. частина Пд. Америки }\end{array}$ & 1840 & $\Pi p$ \\
\hline U. reticulata Sm., Індія, о. Шрі-Ланка & 1805 & $\Pi p$ \\
\hline U. rhododactylos P. Taylor, ендемік Пн. Австралії & 1986 & $\Pi$ Пр \\
\hline U. rigida Benj., ендемік 3х. Тропічної Африки & 1847 & $\mathrm{P}$ \\
\hline U. rostrata A. Fleischm. \& Rivadavia, енд. Бразилії & 2009 & $\mathrm{~T}$ \\
\hline $\begin{array}{l}\text { U. salwinensis Hand.-Mazz., Китай (Пн.-зх. Юаня, Пн-зх. } \\
\text { Хізангу (Тібет) }\end{array}$ & 1936 & л \\
\hline U. sandersonii Oliv., Пд. Африка & 1865 & Л \\
\hline
\end{tabular}


Продовження таблиці 1

\begin{tabular}{|c|c|c|}
\hline Назва виду та поширення & $\begin{array}{c}\text { Рік } \\
\text { відкриття } \\
\end{array}$ & $\begin{array}{l}\text { Екобіоморфологі } \\
\text { чні особливості }\end{array}$ \\
\hline $\begin{array}{l}\text { U. sandwithii P. Taylor, ендемік Бразилії, } \\
\text { Гуйяна, Суринам, Венесуела }\end{array}$ & 1967 & $\mathrm{~T}$ \\
\hline U. scandens Benj., Африка, Азія & 1847 & $\mathrm{~T}$ \\
\hline $\begin{array}{l}\text { U. schultesii Fernandez-Perez, ендемік Пд. Америки } \\
\text { (Колумбія, Венесуела) }\end{array}$ & 1964 & $\mathrm{~T}$ \\
\hline $\begin{array}{l}\text { U. simmonsii Lowrie, Cowie \& Conran, ендемік Австралії } \\
\text { (Північний Квінсленд) }\end{array}$ & 2008 & $\mathrm{~T}$ \\
\hline U. simplex R. Вr., ендемік 3х. Австралії & 1810 & $\mathrm{~T}$ \\
\hline U. simulans Pilger, тропічні Африка, Америка & 1914 & $\mathrm{~T}$ \\
\hline U. singeriana F. Muell., Пн. та Зх. Австралії & 1891 & $\mathrm{~T}$ \\
\hline U. smithiana $\mathrm{R}$. Wight, Індія & 1849 & Пр, Т \\
\hline U. spinomarginata Suksathan \& J. Parn., Таїланд & 2010 & $\mathrm{~T}, Л$ \\
\hline U. spiralis $\mathrm{Sm} .$, Тропічна Африка & 1819 & $\mathrm{~T}$ \\
\hline $\begin{array}{l}\text { U. spruceana Benth. ex Oliv., Пд. Америка } \\
\text { (Бразилія, Венесуела) }\end{array}$ & 1860 & $\Pi p, \mathrm{~T}$ \\
\hline U. stanfieldii P. Taylor, ендемік Ц. та Пд. Америки & 1963 & Пр, Т \\
\hline U. steenisii Р. Taylor, ендемік о. Суматра & 1986 & $\mathrm{~T}, \pi$ \\
\hline U. stellaris L. f., Африка, троп. Азія, Пн. Австралія & 1781 & Впр \\
\hline U. steyermarkii Р. Taylor, ендемік Венесуели & 1967 & Л \\
\hline U. striata Le Conte ex Torr., Пн. Америка & 1819 & Пр \\
\hline U. striatula Sm., від Тропічної Африки до о. Нова Гвінея & 1819 & Е, Л \\
\hline U. stygia Thor, Пн. Свропа, Пн. Америка & 1988 & Нзр \\
\hline U. subramanyamii Janarthanam \& Hеnry, енд. Індії & 1989 & $\mathrm{~T}$ \\
\hline $\begin{array}{l}\text { U. subulata L., Нова Шотландія, Аргентина, троп. } \\
\text { Африка, о. Мадагаскар, Таӥланд, Португалія }\end{array}$ & 1753 & $\mathrm{~T}$ \\
\hline U. tenella $\mathrm{R}$. Вr., Пд. та Пд.-Зх. Австралія & 1810 & $\mathrm{~T}$ \\
\hline $\begin{array}{l}\text { U. tenuicaulis Miki, Пд. Африка, Свропа, Азія, тропічна } \\
\text { Африка, Австралія, о. Нової Зеландії }\end{array}$ & 1935 & Пр \\
\hline U. tenuissima Tutin, ендемік Пд. Америки & 1934 & $\mathrm{~T}$ \\
\hline U. terrae-reginae P. Taylor, Австралія & 1986 & $\mathrm{~T}$ \\
\hline $\begin{array}{l}\text { U. tetraloba P. Taylor, ендемік о. Нова Гвінея та Сьєрра- } \\
\text { Леоне }\end{array}$ & 1963 & $\mathrm{P}$ \\
\hline U. tortilis Welw. ex Oliv., тропічна Африка & 1865 & $\mathrm{~T}$ \\
\hline U. trichophylla Spruce ex Oliv., Ц. та Пд. Америка & 1860 & Пр, T \\
\hline U. tricolor St. Hil., ендемік Пд. Америки & 1833 & $\mathrm{~T}$ \\
\hline U. tridactyla P. Taylor, ендемік 3х. Австралії & 1986 & $\mathrm{~T}$ \\
\hline U. tridentata Sylven, Пд. Бразилія, Уругвай, Аргентина & 1909 & $\mathrm{~T}$ \\
\hline U. triflora P. Taylor, Пн. Австралія & 1986 & $\mathrm{~T}$ \\
\hline U. triloba Вenj., Пд. Америка & 1847 & $\mathrm{~T}$ \\
\hline U. troupinii Р. Taylor, ендемік Африки (ДР Конго) & 1971 & $\mathrm{~T}$ \\
\hline U. tubulata F. Muell., Зх. Австралія & 1875 & Впр \\
\hline U. uliginosa Vahl, Пд.-Сх. Азія, Океанія, Австралія & 1804 & $\Pi p, \mathrm{~T}$ \\
\hline U. uniflora $\mathrm{R}$. Вr., Пн.-сх. Австралія, Тасманія & 1810 & $\mathrm{~T}$ \\
\hline U. unifolia Ruiz \& Pav., Пн. та Пд. Америка & 1797 & T,E \\
\hline U. violacea $\mathrm{R}$. Вr., Австралія & 1810 & $\mathrm{~T}$ \\
\hline U. viscosa Spruce ex Oliv., Ц. та Пд. Америка & 1860 & $\Pi p, \mathrm{~T}$ \\
\hline U. vitellina Ridl., ендемік Малайзії & 1923 & $\mathrm{~T}$ \\
\hline
\end{tabular}


Закінчення таблиці 1

\begin{tabular}{|l|c|c|}
\hline \multicolumn{1}{|c|}{ Назва виду та поширення } & $\begin{array}{c}\text { Рік } \\
\text { відкриття }\end{array}$ & $\begin{array}{c}\text { Екобіоморфологі } \\
\text { чні особливості }\end{array}$ \\
\hline U. volubilis R. Вr., ендемік пд.-зх. частини 3х. Австралії & 1810 & Нзр \\
\hline U. vulgaris L. (tipus), Азія, Свропа & 1753 & Впр \\
\hline U. warburgii Goebel, Китай & 1891 & Т \\
\hline $\begin{array}{l}\text { U. warmingii Kam., ендемік Пд. Америки } \\
\text { (Болівія, Бразилія, Венесуела) }\end{array}$ & 1894 & Впр \\
\hline U. welwitschii Оliv., ендемік Тропічної Африки & 1865 & Т \\
\hline $\begin{array}{l}\text { U. westonii Р. Тауыог, ендемік Зх. Австралії } \\
\text { (Національний парк «Капе ле Гранде») }\end{array}$ & 1986 & Т \\
\hline \multicolumn{1}{|c|}{ U. wightiana Р. Тауlor, ендемік Індії } & 1986 & Т \\
\hline
\end{tabular}

Вир - вільноплаваючі рослини; Вр - водні рослини; Нзр - не закріплені рослини;

Нзир - не закріплені, підводні рослини; Пр - підводні рослини; $P$ - реофіти;

T- терастральні; E-епіфіти; Л-літофіти.

\section{2. Біоморфологічні особливості представників роду Utricularia L.}

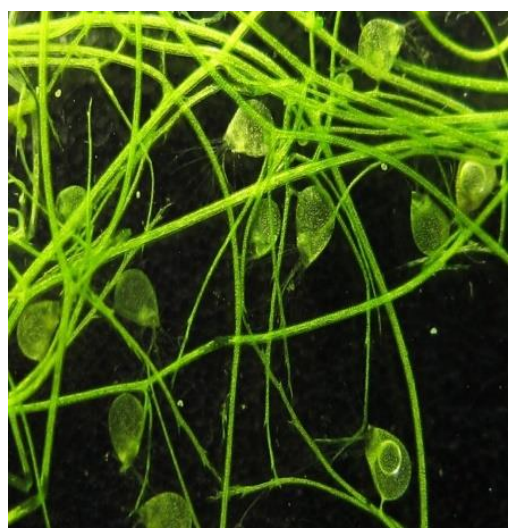

A

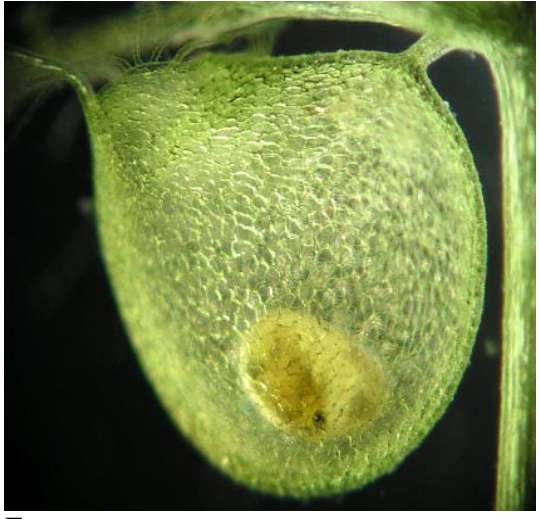

Б

Рис. 2. Пухирці-пастки водного виду Utricularia gibba L.: А - стебла з пухирцями-пастками; Б - пухирець-пастка, х 600

Види роду Utricularia - водні, терастральні, рідше літофіти чи епіфіти із черговими або зібраними в розетки листками, багаторічні й однорічні трав'янисті рослини. Вони ростуть у прісноводних водоймах, на болотах, у вологих місцях. Здебільшого це представники сфагнових торф'яників, гіпново-трав'яних боліт, 3 їхнім специфічним гідрологічним режимом, який і зумовив своєрідний морфогенез видів. Рід Utricularia дістав свою назву через те, що рослини на пагонах (стеблового походження) у воді або у вологому грунті формують пухирці - utriculi (рис. 2 (А, Б)), які призначені для ловлі дрібних рачків, циклопів, дафній, пуголовків, рибок і комах. Ця особливість 
вперше була помічена й описана в 1874 р. німецьким ботаніком і бактеріологом, професором Коном Фердінандом Юліусом (F.J. Cohn), який знайшов у пухирцях водних видів Utricularia велику кількість дрібних ракоподібних, водних тварин і водоростей. Пізніше ці дослідження були повторені Ч. Дарвіном ${ }^{25}$. Життєва форма інтродукованих видів Utricularia, яка визначена за С. Гейні ${ }^{26}$, плейстофіти та водні гемікриптофіти, улігінозофіти, стеноулігінозофіти, геліофіти, гідатофіти, утриуляреїди, ентомофіли, гідрохори. Життєвий цикл водних видів пов'язаний із гідрофазою та прибережною екофазою. У терастральних - iз лімнофазою, прибережною та болотною екофазою. Водні види - R-, K-стратеги. Терастральні - S-стратеги ${ }^{27}$. Тип «пасток» - засмоктувальний, що зумовлено особливостями зростання рослин. Цей тип характеризується утворенням пухирців на пагоні. Пухирці мають отвори, які затуляє вільно звисаючий клапан. Спеціальні залози викачують із пухирця майже всю воду, щоби клапан щільно затулився під тиском води ззовні. Потім виділяється цукриста речовина, що приваблює водну здобич. Щетинки спрямовують здобич до клапана, який швидко відчиняється, щойно жертва торкнеться сигнальних волосків. Тиск змушує клапан відчинятися в середину, унаслідок чого здобич разом із водою засмоктується в пухирець. Далі клапан швидко затуляється, вода викачується і розпочинається перетравлювання улову ${ }^{28}$. У 2011 p. дослідники Франції та Німеччини визнали види роду Utricularia блискавично швидкими хижими рослинами у світі ${ }^{4}$. Під час дослідження пухирців було встановлено, що коли вони «здуваються», у стінках накопичується значна енергія пружності, як у натягнутій тятиві лука. В умовах інтродукції квітування видів роду спостерігається із червня до вересня включно, утворення плодів - із липня до жовтня. Відновлюються рослини вегетативно (пагонами i туріонами) та насінням. 3 морфологічного погляду рід характеризується цілковитою відсутністю кореневої системи і незвичайною пластичністю, або мінливістю решти вегетативних органів. Водні форми (до числа яких належать і всі види, що трапляються в Україні та Співдружності Незалежних Держав) можна поділити на дві групи. Перші - утворюють тільки пагони, що вільно плавають у воді (недалеко від поверхні), густо вкриті дуже розчленованим листками, окремі частки яких мають вигляд 108 c.

${ }^{25}$ Холодний М. Комахоїдні рослини. Київ : Видав-во Академії наук УРСР, 1938. slowakischen Tiefebenen. Bratislava : Vyd-vo SAV, 1960. 487 S.

27 Hejný S. Okologische charakteristik der Wasser und Sumpflanzen in den slowakischen Tiefebenen. Bratislava : Vyd-vo SAV, 1960. 487 S.

${ }_{28}$ Fenner C. Beiträge zur Kenntnis der Anatomie, Entwicklungsgeschichte und Biologie der Laubblätter und Drüsen einiger Insektivoren. Allg. Bot. Z. 93, 1904. S. 335-434. 
коротких ниток, або щетинок. Другі - крім пагонів, що плавають, мають ще інші, які можна назвати якірними, оскільки вони відходять униз і проникають у донний мул, закріплюючи рослину на місці.

Якірні пагони відрізняються від вільно плаваючих тим, що листки їх редуковані. I перші, і другі мають пухирці, які призначені для ловлі здобичі і морфологічно являють собою видозмінені частини листка. У водних видів $U$. vulgaris L. i $U$. neglecta Lehm. є так звані повітряні пагони, спрямовані завжди до поверхні води; вони виступають над нею i покриті на верхівці лускатими листками. Оскільки ці листки на зовнішній поверхні мають багато продихів, їх уважають органами газообміну. У деяких тропічних видів вони досягають особливо великого розвитку і мають вигляд довгих білих ниток, які стирчать своїми верхівками з води. Під час квітування всі представники роду Utricularia утворюють довгий вертикальний квітконіс. У водних видів він завжди виступає над поверхнею води, до того ж при основі його іноді спостерігаються особливі пристосування - плавальні пухирці, за допомогою яких квітконіс зберігає своє вертикальне положення. Це досить об'ємні вирости, що нагадують подушечки із численними розгалуженнями (рис. 3). Усередині вони мають багато камер, відділених одна від одної тонкими перегородками і наповнених повітрям. Квітки у видів Utricularia зигоморфні, двостатеві, зібрані в китицеподібні, колосоподібні або поодинокі суцвіття (рис. 4 (А, В)). Чашечка дволопатева або 4-5-тилопатева, що залишається при плодах. Двогубий віночок із короткою трубкою має при основі шпорки 3 мішкоподібним придатком. Верхня губа віночка дволопатева, нижня трилопатева або суцільна. Тичинки - дві, із плоскими розширеними нитками, що прикріплені до основи віночка. Пиляки одно- або рідше двогніздні. Гінецей із двох плодолистиків; зав'язь верхня, одногніздна, iз численними насінними зачатками; стовпчик дуже короткий, iз дволопатевим рильцем, із нерівними лопатями. Плід - одногніздний, коробочка шароподібної або яйцеподібної форми, іноді видовжений. Розкривається двома або чотирма стулками з нерівними частинами, рідше він однонасінний і не розкривається. Насіння дрібне, із слабо розвиненим ендоспермом. Перехресне запилення у видів роду Utricularia в помірній зоні забезпечується комахами (бджоли, джурчалки, мурахи та мухи), яких приваблює нектар, що знаходиться у шпорці. Вказівником нектару для комах у видів роду Utricularia (приклад - U. vulgaris L.) є помаранчеві смуги на здутті нижньої губи. У $U$. vulgaris здуття на нижній губі, що слугує місцем посадки комах, щільно закриває вхід у квітку. Під вагою комахи нижня губа відхиляється вниз, відкриваючи вхід у квітку, а пиляки, що щільно прилягають до верхньої губи, торкаються голови та спинки комахи. На нижній лопаті рильця наявні жорсткі сосочки, наче зубчики гребінки, при русі над якими комахи знімають пилок із волосків. За відсутності 
комахи може відбуватися самозапилення, завдяки тому, що нижня лопать рильця, яка нависає над пиляками, завертається таким чином, що поверхня рильця їх торкається. У видів Utricularia трапляється клейстогамія (самозапилення i самозапліднення закритих квіток). Насіння більшості видів Utricularia (як і всієї родини Lentibulariaceae) поширюються птахами, до лап яких воно прилипає, або розноситься течією води. Птахи розносять також частини рослин. У деяких видів (U. rigida Benj.) поверхня насінин вкрита клейкою речовиною, що перешкоджає їх змиванню течією. Насіння епіфітних видів (U. striatula Sm. i $U$. nelumbifolia Gardn.) мають крючечки, якими вони кріпляться за мох, а деякі види ( $U$. mannii Oliv.) утворюють декілька тисяч дуже дрібних насінин, що схожі за формою на насіння орхідей i поширюються вітром.

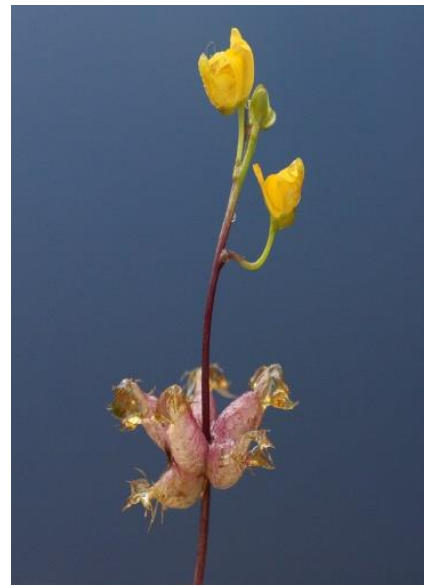

Рис. 3. Квітконіс водної рослини Utricularia intermedia Hayne із плавальними пухирцями 


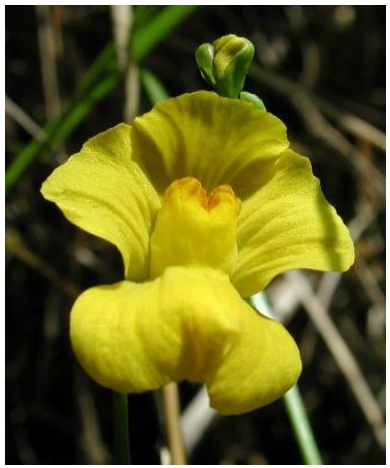

A

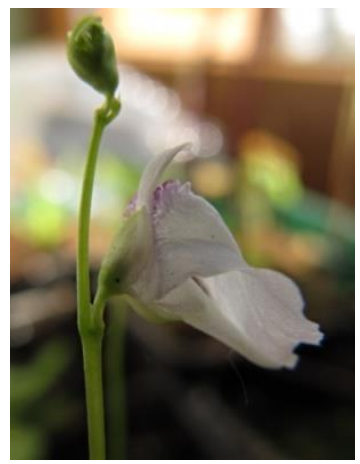

Б

Рис. 4. Квітки інтродукованих видів Utricularia L.: А - водний вид $U$. gibba L.; Б - терастральний вид $U$. livida E. Mey.

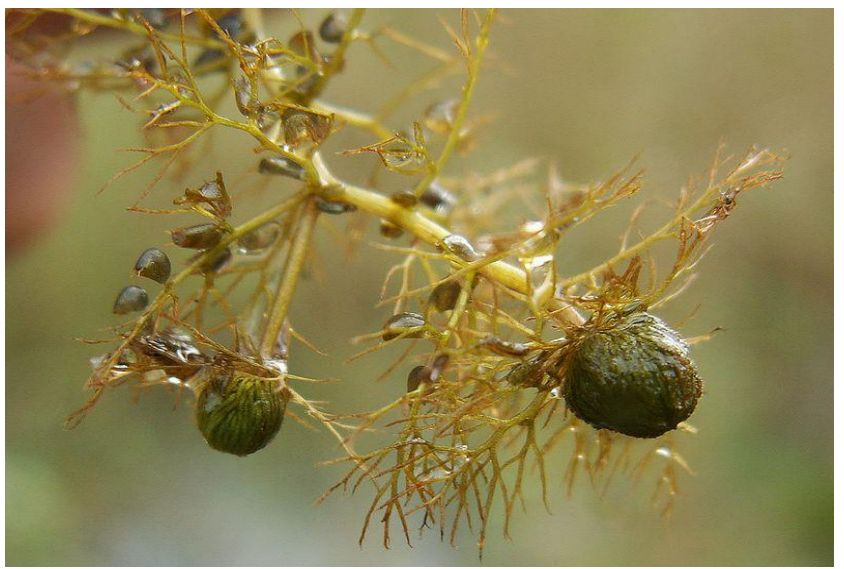

Рис. 5. Туріони водної рослини Utricularia vulgaris L.

У рослин помірних зон із настанням осінніх холодів (особливо у водних видів) на кінцях вегетативних пагонів утворюються зимові бруньки - туріони (відгілки, за В. Гьобелем ${ }^{29}$ ) (рис. 5). Вони мають округлу форму і складаються із щільно притиснених один до одного листків із великим запасом поживних речовин. Відділившись від материнської рослини, ці бруньки падають на дно водойми, тут перезимовують. Весною вони починають розвиватися, пагони, що 3 них утворились, стаючи

${ }^{29}$ Goebel W. Insektivores. Pflanzenbiologische Schilderungen. II-ter Teil. Marburg : N.C. Elwert'sche Verlagsbuchhandlung, 1891. S. 51-174. 
легшими за воду (унаслідок проникнення повітря в міжклітинні простори), спливають на поверхню. Наводимо біоморфо-екологічну характеристику природних видів, поширених в Україні: Utricularia australis - водна, трав'яниста, багаторічна рослина, що вільно плаває в поверхневому шарі води, плейстофіт. Коренева система редукована. Стебла завдовжки 10-60 см, інколи можуть сягати 1,5 м. Листки кількаразово розсічені на ниткоподібно-лінійні частки, частина яких перетворена на повітряні ловчі пухирці, кількість яких на кожному з пагонів коливається від 80 до 200 штук. Суцвіття - 3-12-квіткові китеці - виступає над водою. Вісь суцвіття змієподібно вигнута та потоншується біля верхівки. Квітконіжки у 3-5 разів довші за приквітки. Віночок 12-18 мм завдовжки, жовтий із червоними смужками, двогубий. Верхня губа у 2-3 рази довша за випуклу нижню. Шпорка загострена, завдовжки 0,5-7,5 мм. Маточка 3 майже сидячою дволопатевою приймочкою складається із двох плодолистиків. Тичинки вільні. Пилкові зерна сплющено-кулясті, в обрисі з полюса $12-15$-лопатеві, 3 малопомітною текстурою ${ }^{30}$. Плід - багатонасінна куляста коробочка завширшки 0,4 мм. Вид віддає перевагу стоячим або малопроточним, чистим і добре прогрітим водоймам, але, на відміну від інших видів, полюбляє воду 3 високим вмістом мінеральних солей. Рослини зростають у ставках, меліоративних каналах, старицях, озерах, які живляться водою мінеральних джерел. До значень $\mathrm{pH}$ невибаглива переносить як лужні, так і кислі показники. У передгір'ях підіймається до висоти 100-115 м над рівнем моря. Формує рослинні асоціації, у яких частка цього виду доходить до 20-80\%. Квітують природні популяції в червні - липні, плодоносять у серпні - вересні. Інтродуковані рослини квітувати починають у кінці травня, масово - у серпні, поодиноко - у вересні $^{31}$. Плодоношення в інтродукованих рослин не спостерігалось, розмножуються вегетативно ${ }^{32}$. Несприятливі умови рослини переносять за

30 Цимбалюк 3., Мосякін С., Безусько Л. Порівняльно-морфологічна характеристика пилкових зерен видів Pinguicula L. та Utricularia L. флори України. Український ботанічний журнал. 2007. Т. 65. № 4. С. 520-534.

31 Дідух А., Мазур Т., Дідух М. Біоморфологічні особливості роду Utricularia L. у Ботанічному саду ім. акад. О.В. Фоміна. Вісник Київського університету. Інтродукиія та збереження рослинного різноманіття. 2016. Вип. 1 (34) 16. С. 14-18 ; Дідух А., Мазур Т., Дідух М. Систематична характеристика колекції комахоїдних рослин Ботанічного саду ім. акад. О.В. Фоміна (родина Lentibulariaceae Rich., piд Utricularia L.). Природничий альманах. Біологічні науки : збірник наукових праць. Вип. 23. Херсон, 2016. С. 63-75.

32 Дідух А., Мазур Т., Дідух М. Біоморфологічні особливості роду Utricularia L. у Ботанічному саду ім. акад. О.В Фоміна. Вісник Київського університету. Інтродукція та збереження рослинного різноманіття. 2016. Вип. 1 (34) 16. С. 14-18 ; Дідух А., Мазур Т., Дідух М. Систематична характеристика колекції комахоїдних рослин Ботанічного саду ім. акад. О.В. Фоміна (родина Lentibulariaceae Rich., рід Utricularia L.). Природничий альманах. Біологічні науки : збірник наукових праць. Вип. 23. Херсон, 2016. С. 63-75; Дідух А., Мазур Т., Дідух М. Видовий склад роду Utricularia L. та його екобіоморфологічні особливості (родина Lentibulariaceae Rich.). Природничий альманах. Біологічні науки : збірник наукових праць. Вип. 23. Херсон, 2016. С. $43-62$. 
допомогою особливих зимуючих бруньок (туріонів). Первинний ареал охоплював Австралію та північну частину Нової Зеландії, звідки цей вид поширився до теплих і помірних регіонів інших континентів. Нині U. australis можна знайти в Китаї, на Японських островах, у Центральній та Південній Африці, а в Свропі він розповсюджений по всіх узбережних ділянках, включно із Середземномор'ям, Атлантичним узбережжям, півднем Скандинавії, заходом європейської частини Росії. В Україні іiї вперше описали на Закарпатті ${ }^{33}$.

Utricularia gibba - водна, дрібна, трав'яниста багаторічна рослина, плейстофіт. Коренева система редукована. Стебла завдовжки 15-20 см, галузчасті. Листки чергові, численні, вилчасто розсічені (до 4-8 сегментів), завдовжки 0,5-1,5 см, завширшки 0,1-3,0 мм. Пухирці яйцеподібні на ніжці, 1,0-2,5 мм завдовжки. Вхід до пухирця боковий, має два головних, вильчастих придатки, менші з них розміщені на вході до пухирця. Суцвіття - 6-12-квіткові, китиці на квітконосі 15-20 (30) см заввишки, що підіймається над поверхнею води. Квітки на квітконіжках. Віночок двогубий, жовтий із червоними смужками. Верхня губа округла, пласка, ділиться на три долі. Шпорка циліндрична 3 мішкоподібним придатком. Нижня губа менша за верхню, еліптична, майже округла. Плід - багатонасінна куляста коробочка завширшки $0,2-0,3$ мм. Рослина зростає у прісних замкнутих та малопроточних водоймах - озерах, старицях, канавах і мочарах. Віддає перевагу добре освітленим водоймам (геліофіт) із мулувато-піщаним або мулуватоторфовим дном. Полюбляє воду з кислою реакцією, низьким вмістом мінеральних речовин і досить високим вмістом органічних. Різке коливання рівня води переносить погано. Квітування природних популяцій зазначено в липні - серпні, плодоносить (рідко) у вересні. Інтродуковані рослини квітувати починають у кінці липня та продовжують до вересня включно. У відтворенні цієї рослини головну роль відіграє вегетативне розмноження поділом рослини на частини. В умовах інтродукції не плодоносить ${ }^{34}$. Ареал - пантропічний, охоплює Сполучені Штати Америки (крім Аляски та гірських районів), Канаду, Центральну і Південну Америку, Австралію, Африку, Азію, Китай, Японію, Іспанію, Тасманію, Нову Гвінею, північну частину Нової Зеландії. У природі рослини утворюють локальні скупчення та куртини. Плаває у верхніх шарах води на нитчастих водоростях, відмерлих та живих рослинах, використовуючи їх як опору під час

\footnotetext{
${ }^{33}$ Utricularia australis R. Br. (Lentibulariaceae) - новий вид для флори Прикарпаття / I. Данилик та ін. Украӥнський ботанічний журнал. 2007. Т. 64. № 2. С. 242-246.

${ }^{34}$ Дідух А., Мазур Т., Дідух М. Біоморфологічні особливості роду Utricularia L. у Ботанічному саду ім. акад. О.В Фоміна. Вісник Київського університету. Інтродукиія та збереження рослинного різноманіття. 2016. Вип. 1 (34) 16. С. 14-18 ; Дідух А., Мазур Т., Дідух М. Систематична характеристика колекції комахоїдних рослин Ботанічного саду ім. акад. О.В. Фоміна (родина Lentibulariaceae Rich., рід Utricularia L.). Природничий альманах. Біологічні науки : збірник наукових праць. Вип. 23. Херсон, 2016. С. 63-75.
} 
квітування. На скорочення популяцій впливають різкі зміни рівня води, іiі забруднення, проведення меліораційних робіт.

Utricularia intermedia Hayne - водна, трав'яниста, багаторічна рослина, плейстофіт. Коренева система редукована. Стебла завдовжки 10-20 см. Вегетативні пагони двох типів: одні несуть зелені листки із загостреними, щетиноподібними дихотомічно розсіченими долями. Інші, безбарвні, мають пухирці із клапанами. Листки завдовжки 0,4-20 мм, завширшки 0,7-32 мм, пухирці до 0,5 мм завширшки. Суцвіття - 2-6-квіткові китиці, що підіймаються над поверхнею води на 10-20 см. Квітки двостатеві, 12-15 мм завдовжки. Віночок двогубий, жовтий із червоними смужками. Нижня губа округла, пласка, тупа. Шпорка циліндрична. Плід - куляста коробочка завширшки 0,3-0,4 мм. Рослина зростає $\mathrm{y}$ прісних замкнутих водоймах, на болотах i торфовищах, на глибині 10-150 см. Віддає перевагу водоймам із постійним рівнем води, низьким або середнім вмістом органічних речовин, мулувато-торфовими чи торфовими донними відкладеннями, часто утворює угруповання 3 видами роду Sphagnum L. або близьким видом - U. Minor L. Початок квітування природних популяцій зазначений у червні, рясне квітування починається в липні і триває до серпня. Плодоносить (рідко) у вересні. В умовах інтродукції квітування спостерігається з липня і триває до вересня. Плодоносить із вересня до жовтня, за умови штучного запилення. Несприятливі умови рослини переносять за допомогою туріонів, вони ж $є$ і головним засобом вегетативного розмноження ${ }^{35}$. Насіннєве відтворення відіграє другорядну роль. Ареал виду циркумполярний, що охоплює помірні області Євразії та Північної Америки. Розповсюджений по всій Європі, від Скандинавії до Середземномор'я, а також у Сибіру, на Далекому Сході, Кавказі, Японських островах і в Китаї. В Україні U. intermedia поширена переважно в Поліссі, лише зрідка - у Лісостепі. Найбільшими загрозами для виду $U$. intermedia $є$ різке коливання рівня води у водоймах, iї забруднення, а також осушення водойм.

Utricularia minor - водна, трав'яниста, багаторічна рослина, що плаває у воді або лежить у прибережному мулі, плейстофіт. Коренева система редукована. Туріони голі. Пагони завдовжки 5-20 (зрідка до 40) см. Листки чергові, дихотомічно розсічені на вузьколінійні долі, усі однакові за будовою, несуть ловчі пухирці завширшки 1-1,5 мм. Кожна доля завдовжки 0,2-18 мм, завширшки

35 Дідух А., Мазур Т., Дідух М. Біоморфологічні особливості роду Utricularia L. у Ботанічному саду ім. акад. О.В Фоміна. Вісник Київського університету. Інтродукиія та збереження рослинного різноманіття. 2016. Вип. 1 (34) 16. С. 14-18 ; Дідух А., Мазур Т., Дідух М. Систематична характеристика колекції комахоїдних рослин Ботанічного саду ім. акад. О.В. Фоміна (родина Lentibulariaceae Rich., piд Utricularia L.). Природничий альманах. Біологічні науки : збірник наукових праць. Вип. 23. Херсон, 2016. С. 63-75. 
0,4-20 мм. Суцвіття - 2-6-квіткові китиці на квітконосі 5-15 см заввишки, що підіймається над поверхнею води. Віночок 0,7-12 мм завдовжки, світло-жовтий із червоними смужками, із короткою трубочкою та двогубим відгином. Шпорка коротка, нижня губа віночка видовжена. Плід - багатонасінна куляста коробочка завширшки 0,2-2,5 мм. Рослина зростає у прісних замкнутих та малопроточних водоймах - озерах, старицях. Віддає перевагу добре освітленим водоймам (геліофіт) із мулувато-піщаним або мулуватоторфовим дном, також може зростати на обводнених торфовищах, на глибині 5-100 см. Полюбляє воду з кислою реакцією, низьким вмістом мінеральних речовин і досить високим вмістом органічних. Різке коливання рівня води переносить погано. У природі квітує в липні - серпні, плодоносить (рідко) у вересні. Інтродуковані рослини квітування починають у кінці липня та продовжують до вересня включно. У відтворенні цієї рослини головну роль відіграє вегетативне розмноження за допомогою туріонів або поділом рослини на частини. У природі насіннєве розмноження другорядне та спостерігається зрідка. Для отримання насіння в умовах інтродукції необхідне штучне запилення ${ }^{36}$. Ареал охоплює помірні області Євразії. Рослини U. minor зростають у водоймах Середньої, Західної Свропи, Скандинавії, Сибіру, Далекого Сходу, Японських островів, Китаю, Гімалаїв, Середньої Азії, Кавказу, а також у Північній Америці. В Україні $U$. minor поширена переважно в Поліссі, інколи - у Лісостепі, у степових районах трапляється в долинах великих річок. У природі рослини утворюють локальні скупчення, після їх відмирання рештки складають основу новоутвореного шару торфу. На скорочення популяцій впливають різкі зміни рівня води, іiі забруднення, проведення меліораційних робіт.

Utricularia vulgaris - водна, трав'яниста, багаторічна рослина, що вільно плаває в поверхневому шарі води або заякоряється у придонному шарі мулу, плейстофіт. Коренева система редукована. Туріони - кулясті, до 1 см діаметром. Стебла завдовжки 25-80 (зрідка до 100) см. Листки чергові, густо вкриті розсіченими на ниткоподібні та лінійні частки, несуть ловчі пухирці завширшки $0,2-0,3$ мм. Кожна доля завдовжки 1,0-2,5 см, завширшки 0,5-10 мм. Суцвіття - 4-15-квіткові китиці на квітконосі 15-40 см заввишки,

${ }^{36}$ Дідух А., Мазур Т., Дідух М. Біоморфологічні особливості роду Utricularia L. у Ботанічному саду ім. акад. О.В Фоміна. Вісник Київського університету. Інтродукиія та збереження рослинного різноманіття. 2016. Вип. 1 (34) 16. С. 14-18 ; Дідух А., Мазур Т., Дідух М. Систематична характеристика колекції комахоїдних рослин Ботанічного саду ім. акад. О.В. Фоміна (родина Lentibulariaceae Rich., piд Utricularia L.). Природничий альманах. Біологічні науки : збірник наукових праць. Вип. 23. Херсон, 2016. С. 63-75. 
що підіймається над поверхнею води. Віночок 0,7-12 мм завдовжки, світло-жовтий. Зів віночка (місце переходу трубки віночка у відгин) червоно-брунатний. Верхня губа округла, 0,7-10 мм завдовжки. Шпорка конусоподібна, 0,6-0,8 мм завдовжки, нижня губа віночка має знизу опушення 13-16 мм завдовжки. Плід - багатонасінна куляста коробочка завширшки 0,6 мм. Насіння численне, дрібне. Рослина зростає у прісних замкнутих та малопроточних водоймах озерах, старицях i канавах. Віддає перевагу добре освітленим водоймам із мулувато-піщаним або мулувато-торфовим дном на глибині 25-100 см. Полюбляє воду з кислою реакцією і досить високим вмістом органічних решток. Зростає на ділянках, які захищені від потоків вітру. Коливання рівня води переносить погано. Природні популяції квітують у липні - серпні, плодоносять у вересні. Інтродуковані рослини, що зростають у відкритому грунті, квітують у серпні та рідко плодоносять. У відтворенні цієї рослини головну роль відіграє вегетативне розмноження за допомогою туріонів або поділом рослини на частини ${ }^{37}$. Цей вид $\epsilon$ найбільш типовим європейським представником. Ареал охоплює помірні області Європи, Північної Америки, зростає у тропічних та субтропічних водоймах Австралії, Африки й Азії. В Україні U. vulgaris спорадично поширена у водоймах Південного Бугу (Згар, Ров, Десна, Соб, Уманка, Гнилий Тікач, Велика Вись), Дністра (Мурафа), Дніпра (Рось, Тясмин, Трубіж, Сула, Ворскла), Сіверського Дінця (Вовча, Мжа). На регіональному рівні охороняється в Полтавській, Черкаській та Харківській областях.

Представлені види колекції Ботанічного саду відносяться до двох підродин (Subgenus Bivalvaria та Subgenus Utricularia) та чотирьох секцій: Section Calpidisca - U. livida, Section Oligocista U. prehensilis, Section Foliosa - U. tricolor; Section Utricularia $U$. australis, $U$. gibba, $U$. intermedia, $U$. minor, $U$. vulgaris. Інтродуковані рослини колекції Ботанічного саду U. Livida, поширені в Ефіопії, Капській провінції, Мексиці, на острові Мадагаскар. Ареал U. prehensilis припадає на Tропічну Африку (Ангола, ПАР, Демократична Республіка Конго, Ефіопія, Кенія, о. Мадагаскар), Південну Африку, Танзанію, Замбію та Зімбабве, де вона має невеликі популящіï. Utricularia tricolor - ендемік Південної Америки (Бразилія, Венесуела, Колумбія та Парагвай). Ці три тропічні види відносяться до багаторічних, трав'янистих,

${ }^{37}$ Дідух А., Мазур Т., Дідух М. Біоморфологічні особливості роду Utricularia L. у Ботанічному саду ім. акад. О.В Фоміна. Вісник Київського університету. Інтродукиія та збереження рослинного різноманіття. 2016. Вип. 1 (34) 16. С. 14-18 ; Дідух А., Мазур Т., Дідух М. Систематична характеристика колекції комахоїдних рослин Ботанічного саду ім. акад. О.В. Фоміна (родина Lentibulariaceae Rich., рід Utricularia L.). Природничий альманах. Біологічні науки : збірник наукових праць. Вип. 23. Херсон, 2016. С. 63-75. 
терастральних рослин ${ }^{38}$. Принцип поділу на екобіоморфологічні групи загального списку видів роду дозволяє заздалегідь спланувати створення нових засік, мочар із постійно вологим чи періодично обсихаючим грунтом і догляд за ними. Наводимо опрацьований загальний список видів роду Utricularia (табл. 1) (рис. 6). Із загального світового списку роду Utricularia виділено три екобіологічні групи: водні, терастральні, літофітно-епіфітні, які мають дев'ятнадцять підгруп (табл. 1; 2). Водні види налічують дев'ять підгруп, терастральні - дві підгрупи, літофітно-епіфітні вісім підгруп (табл. 2). До водних належать - 78, до терастральних 145, до епіфітно-літофітних - 45 видів. Встановлено, що водні рослини становлять $33,9 \%$, терастральні - $63 \%$, а літофітно-епіфітні - 19,5\% від загальної кількості видів. Серед них є такі, що можуть перебувати у двох і навіть у трьох підгрупах водночас. Сучасний центр видового різноманіття роду Utricularia зосереджений у Південній Америці, де зростає найбільше представників. Ендемічні та реліктові види поширені також в Австралії, Африці, Азії, Індії, Північній Америці та Європі. Раритетні види зосереджені і на островах: Куба, Мадагаскар, Нова Гвінея, Нова Зеландія, ШріЛанка, Ява. Терастральні (болотні) види відрізняються від водних переважно тим, що їхнє листя, яке знаходиться на поверхні (у повітрі), має суцільні, нерозчленовані пластинки. Іноді в нижнього листя пластинки бувають роздільні. Відсутня коренева система замінена тонкими розгалуженими пагонами стеблового походження, які закріплюють рослину у грунті і постачають їй воду та мінеральні солі, тобто виконують ті самі функції, що і справжні корені. Крім того, вони несуть багато пухирців; отже, терастральні види знаходяться не у воді, а у вологому грунті. У деяких терастральних видів при основі квітконосів є особливі вирости - так звані ризоїди, призначені для забезпечення більшої стійкості стебла із квітами та плодами. Епіфітні види роду Utricularia ростуть, закріплюючись у корі, в опалому листі, між стовбурами дерев і в моху. Це бульбоподібні та листопадні рослини, які запасають у бульбах воду, яку використовують під час посухи ${ }^{39}$.

${ }^{38}$ Дідух А., Мазур Т., Дідух М. Біоморфологічні особливості роду Utricularia L. у Ботанічному саду ім. акад. О.В Фоміна. Вісник Київського університету. Інтродукція та збереження рослинного різноманіття. 2016. Вип. 1 (34) 16. С. 14-18 ; Дідух А., Мазур Т., Дідух М. Систематична характеристика колекції комахоїдних рослин Ботанічного саду ім. акад. О.В. Фоміна (родина Lentibulariaceae Rich., piд Utricularia L.). Природничий альманах. Біологічні науки : збірник наукових праць. Вип. 23. Херсон, 2016. С. 63-75 ; Дідух А., Мазур Т., Дідух М. Видовий склад роду Utricularia L. та його екобіоморфологічні особливості (родина Lentibulariaceae Rich.). Природничий альманах. Біологічні науки : збірник наукових праць. Вип. 23. Херсон, 2016. C. 43-62.

${ }^{39}$ Darwin Ch. Insectivorous plants. $1875.361 \mathrm{p}$. 


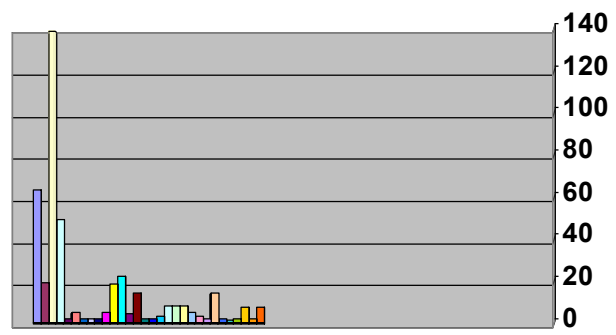

\begin{tabular}{|ll|}
\hline$\square$ Австралія & $\square$ Азія \\
$\square$ Америка & $\square$ Африка \\
$\square$ Бенгал & $\square$ Бірма \\
$\square$ Борнео & $\square$ Гімалаї \\
Гондурас & $\square$ В'єтнам \\
$\square$ Європа & $\square$ Індія \\
$\square$ п-ів Індокитай & $\square$ Китай \\
$\square$ п-ів Корея & $\square$ о-ів Куба \\
$\square$ Лаос & $\square$ о-ів Мадагаскар \\
$\square$ Малазия & $\square$ о-ів Нова Гвінея \\
$\square$ Непал & $\square$ о-ви Нової Зеландії \\
$\square$ Океанія & $\square$ Таїланд \\
$\square$ Тасманія & $\square$ Уссурійськ \\
$\square$ Філіппінські о-ви & $\square$ о-ів Шрі-Ланка \\
$\square$ о-ів Ява & $\square$ Японія \\
\hline
\end{tabular}

\section{Рис. 6. Кількість видів роду Utricularia L. у центрах видового різноманіття}

Деякі ендемічні епіфітні види роду Utricularia поселяються в «цистернах» рослин родини Bromeliaceae Juss. - заглибинах у вигляді чаш, утворених щільно прилеглими одна до одної основними частинами листків. Тут зберігається дощова вода, і в ній завжди є багато живих істот - дрібних тварин, які й служать їжею для цих видів. Характер здобичі, яку ловлять види Utricularia, залежить від того, де розташовані їхні пастки, - у воді, мулі чи грунті, але завжди це дуже дрібні тварини, бо розміри пухирців незначні. Пухирці терастральних, тропічних видів являють собою тонкостінні напівпрозорі порожні утвори, вхідні отвори яких мають форму лійки, що звужується в середину, і закриті пружним клапаном, вільний край якого впирається в підковоподібне потовщення (рис. 7 (А, Б)). По краях ці отвори звичайно усаджені довгими щетинками (антенами); іноді тут є масивні виступи у формі пластинок або хоботків (рис. 7 (В)). 


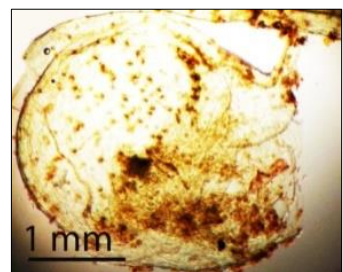

A

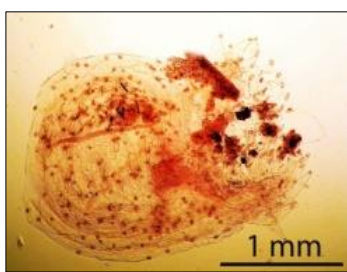

Б

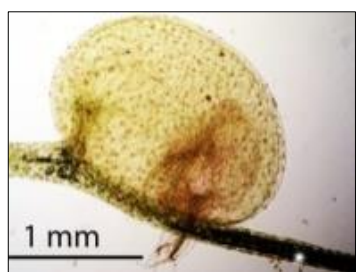

B

Рис. 7 Листки-пастки інтродукованих видів роду Utricularia L.: A - U. tricolor A. St.- Hil; Б - U. livida E. Mey.; $\mathrm{B}-U$. prehensilis E. Mey.

Головне призначення всіх цих пасток полягає в тому, щоб направляти малих плаваючих і повзаючих тварин до вхідного отвору. Для цього ж служить сахаристий слиз, який виділяється особливими залозками. Крім того, антени й інші вирости не дозволяють наближатись до отворів більшим тваринам, які могли б попсувати пухирці. Пухирцям водних видів Utricularia властиві «ковтальні» рухи. Джерелом рушійної сили цих рухів $\epsilon$ чотирилопасні волоски, які в незначній кількості вкривають стінки пухирців ізсередини ${ }^{40}$. Волоски являють собою вбирні залозки, які безперервно й енергійно всмоктують воду з порожнини пухирця. Оскільки вхідний отвір щільно закритий клапаном, то зі зменшенням кількості води в порожнині бокові стінки пухирця поступово втягуються всередину. Ця деформація живої дуже тургесцентної тканини супроводжується виникненням у ній еластичної напруги: вдавлені всередину стінки намагаються набрати початкової форми, але цьому перешкоджає сила зчеплення їx із частками води ізчеплення (когезія) цих часток одна 3 одною. Якщо тепер злегка відкрити клапан, натиснувши на нього тонкою голкою або волоском, то зовнішня вода із силою вривається через утворений отвір усередину, бокові стінки пухирця випрямляються. У природі таке відкривання клапана стимулюється малими плаваючими (і повзаючими) тваринами. Особливо легко клапан відкривається тоді, коли ці тварини дотикаються до розміщених на зовнішній поверхні клапана чотирьох довгих щетинкоподібних волосків. Ці волоски діють на зразок важелів, і достатньо найлегшого натискання на них, щоби клапан відстав від подушечки, яка служить йому опорою. Потік води, що водночас виникає, захоплює тварин і вносить їх усередину порожнини, після чого еластичний клапан повертається у своє початкове положення, вхідний отвір знову закривається. Отже, пухирець Utricularia являє собою живий когезійний механізм. Пухирець, який щойно проковтнув здобич, упродовж деякого часу не може робити нових ковтальних рухів, бо не має потрібної для цього еластичної напруги стінок. Однак уже через

\footnotetext{
${ }^{40}$ Withycombe C. On the function of the biadders in Utricularia vulgaris. The Journal of the Linnean Society. Botany. 1924. V. 46. P. 401.
} 
15-20 хвилин, завдяки роботі чотирилопасних залозок, які висисають воду, він знов «заряджається» достатньою кількістю потенціальної енергії, знов готовий до дії. У будові і фізіологічних властивостях пухирців Utricularia $€$ ціла низка особливостей, які забезпечують безвідмовну роботу їхнього когезійного механізму. Стінки їх складаються із клітин, надзвичайно мало прохідних для води. Проникнення іiі всередину шляхом осмотичного тиску через оболонки і протоплазму цих клітин майже неможливе. Щільне з'єднання клапана 3 опорною подушечкою досягається наявністю на останній кутикулярного валика (velum). Для цього тут служить слиз, який рясно виділяється особливими залозками. Сплющення пухирця під час висисання 3 нього води чотирилопасними волосками супроводжується вигинанням клапана назовні, унаслідок чого він ще щільніше закриває вхідний отвір. Пухирці роду Utricularia являють собою дуже досконалий і найшвидший апарат у світі для ловлі дрібних тварин. За проведеними дослідженнями, форма, розміри, розміщення пухирців є видовою ознакою. Встановлено, що робота всисних залозок, безпосереднім завданням яких $\epsilon$ вбирання поживних речовин із порожнини пухирця, водночас служить джерелом енергії, потрібної для ловлі здобичі. Це $\epsilon$ вияв «принципу економії сил», який, очевидно, відіграв не останню роль у процесі адаптацій, добору і вдосконалювання найскладніших пристосувань у вищих водних рослинних форм. Про досконалість пухирців видів роду Utricularia свідчить і велика кількість здобичі, яка знаходиться в них ${ }^{41}$. Підрахунки показали, що в одному екземплярі $U$. vulgaris, завдовжки 220 см, було більше 150000 пійманих нижчих ракоподібних і велика кількість різних Protozoa. 3 останніх деякі (наприклад, Paramaecium i Stentor) швидко перетравлюються, тоді як інші (наприклад, Euglena) залишаються в пухирцях порівняно довгий час живими і зберігають свою рухливість. Більші тварини потрапляють значно рідше: іноді в пухирцях знаходили личинок жуків, бабок, мальків риби і пуголовків. Чарльзу Дарвіну не вдалося з'ясувати, чи мають пухирці водних видів роду Utricularia здатність виділяти протеолітичні й інші ферменти. Це питання було розв'язане пізніше. Так, у пухирцях зазначено виділення протеолітичного ферменту типу трипсину i, крім того, бензойної кислоти, яка відіграє роль антисептичної речовини. Виявлено також значну кількість найрізноманітніших бактерій, які беруть участь у розкладі білкових та інших органічних речовин пійманих i вбитих тварин. У витяжках із пухирців U. vulgaris знайдено дві протеази, з яких одна сильніше діс в кислому, друга в нейтральному розчині. У витяжках зі звичайного листя цієї рослини протеолітичних ферментів не виявлено ${ }^{42}$.

41 Hegner R. The interrelations of Protozoa and the utricles of Utricularia. Biology Bulletin. 1926. V. 50. P. 239-270.

${ }_{42}$ Fenner C. Beiträge zur Kenntnis der Anatomie, Entwicklungsgeschichte und Biologie der Laubblätter und Drüsen einiger Insektivoren. Allg. Bot. 1904. Z. 93. S. 335-434; Адова А. К вопросу о ферментах Utricularia vulgaris. Журнал Русского ботанического общества. 1924. Т. 9. С. 189 ; Stutzer M. Zur Biologie der Utricuiaria vulgaris. Areh. Hydrobiol. 1926. Bd. 17. S. 730. 
Слабка прохідність стінок пухирців водних видів Utricularia, відзначена деякими дослідниками, очевидно, охороняє продукти гідролізу від дифузії в навколишню воду i забезпечує повне вбирання їх залозками, які розташовані на внутрішній поверхні пухирця. Здатність перетравлювати спійманих тварин пухирці водних видів Utricularia мають тільки на певній стадії їхнього розвитку - у молодому віці. Що стосується старіших пухирців, то в них переважають процеси бактеріального розкладу органічних речовин. Перетравлювання пійманих тварин супроводжується нагромадженням краплинок жиру у клітинах чотирилопасних залозок, які вкривають стінки пухирців ізсередини. Уважається, що цей жир утворюється тут завдяки лецитину, який проникає всередину цих клітин крізь їхні оболонки.

Інтродуковані водні рослини роду Utricularia можна вирощувати в басейнах будь-якої геометричної форми: округлих, овальних, квадратних, трикутних тощо, із гнучкою, жорсткою та бетонованою гідроізоляцією і рівним дном. У відкритому грунті помірної зони влітку утримують майже всі види роду. Необхідними умовами для тривалого утримання видів Utricularia є глибина водної товщі до 20-30 см і заздалегідь сплановані та створені літоральні зони, які будуть виходити на берег, що дозволить влітку утримувати в горщиках і болотні тропічні види, а водним - активно квітувати в «подушках», утворених нитчастими водоростями. За наявності спускних водойм, у яких вода спускається під зиму, зимівля рослин можлива тільки в захищеному грунті. Узимку водні види помірної зони утримують у неглибоких басейнах чи акваріумах, а тропічні, терастральні - у засіках чи піддонах із глибиною водної товщі до 10 см. В умовах захищеного грунту підтримується середня максимальна температура повітря $+28^{\circ} \mathrm{C}$, абсолютний максимум $+30,5^{\circ} \mathrm{C}$; середня мінімальна $-+17^{\circ} \mathrm{C}$, абсолютний мінімум $-+11^{\circ} \mathrm{C}$. Середня максимальна температура води в басейнах $-+22^{\circ} \mathrm{C}$, абсолютний максимум $-+25^{\circ} \mathrm{C}$; середня мінімальна $-+15^{\circ} \mathrm{C}$, абсолютний мінімум $+10^{\circ} \mathrm{C}$. Максимальна відносна вологість повітря - 95\%, мінімальна $75 \%$. Максимальне освітлення - 50000 лк (червень), мінімальне - 500 лк (грудень, січень). Терастральні види роду більш світлолюбні. Для оптимізації газового режиму здійснювалося додаткове постачання повітря компресорним способом. На підставі проведених досліджень для культивування рекомендовано вегетативне розмноження, яке ефективніше за насіннєве. Фаза квітування в таких рослин настає у травні наступного року в умовах захищеного грунту або в червні - липні у відкритому грунті. Субстрат для болотних видів повинен бути пухким. Для його створення використовують торф, перліт, річковий пісок, різаний сфагнум, деревне вугілля в таких пропорціях: $4: 2: 1: 0,5: 0,5$. Цей склад субстрату максимально схожий на природний і відповідає $\mathrm{pH}$ 5-6. Під час вирощування болотних видів Utricularia в умовах захищеного грунту до верхнього шару субстрату додають живий сфагнум, але треба стежити за тим, щоб він не пригнічував рослини своїм активним розвитком і механічно знімати в разі розростання. Для 
висадки рослин використовують пластмасові горщики 3 отворами. Пересадку болотних видів проводять навесні (кінець лютого - початок березня), до фази бутонізації. Штучне підживлення водних видів (раз на місяць) можна проводити дафніями та циклопом, терастральних видів трубочником звичайним (Tubifex tubifex, O. Müller), який додають невеличкими грудочками у грунт чи воду.

Інтродукція терастральних видів роду Utricularia вимагає створення обводнених мочар i латеральних зон із шаром торфу та мохів. Більшість із них становлять рослини оранжереї із тропічним вологим кліматом, які потребують штучних, підвищеної вологості місцин, у вигляді засік і басейнів із глибиною води 10 см взимку, 30-40 см улітку. Деякі види, в умовах інтродукції, можна утримувати лише в тераріумах зі штучними водоспадами, що підтримуються туманним зрошення (дрібнодисперсійний полив), який дозволяє створювати оптимальні умови для ефективного росту та розмноження цієї групи рослин.

Таблиця 2

Список груп та підгруп роду Utricularia L. залежно від екобіологічних особливостей

\begin{tabular}{|c|c|c|c|c|c|c|c|c|c|c|c|c|c|c|c|c|c|c|}
\hline \multicolumn{9}{|c|}{ Водні } & \multicolumn{2}{|c|}{$\begin{array}{c}\text { Tера- } \\
\text { стральні }\end{array}$} & \multicolumn{8}{|c|}{ Літофітно-епіфітні } \\
\hline 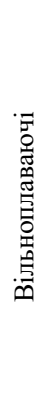 & 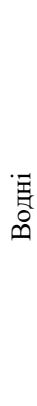 & 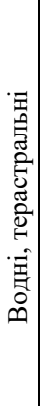 & 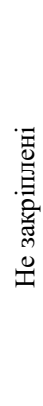 & 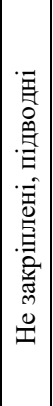 & 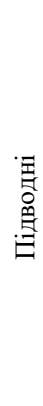 & 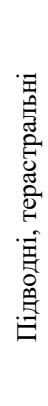 & 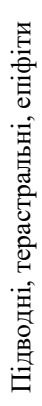 & 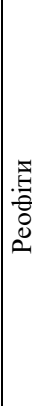 & 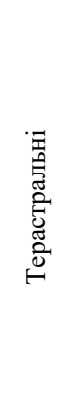 & 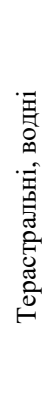 & 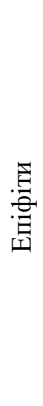 & 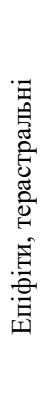 & 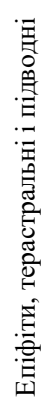 & 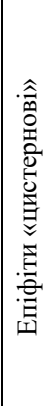 & 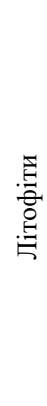 & 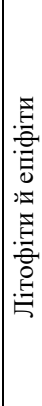 & 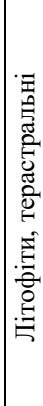 & 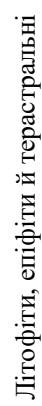 \\
\hline 29 & 2 & 2 & 9 & 3 & 6 & 16 & 3 & 8 & 126 & 19 & 6 & 4 & 3 & 1 & 20 & 1 & 9 & 1 \\
\hline \multicolumn{2}{|c|}{ Усього } & \multicolumn{7}{|c|}{78} & \multicolumn{2}{|c|}{145} & \multicolumn{8}{|c|}{45} \\
\hline
\end{tabular}

За сучасними дослідженнями, рід має три підродини та тридцять чотири секції, які наводимо нижче ${ }^{43}$.

43 Taylor P. The genus Utricularia : A taxonomic monograph. Kew Bulletin Additional. Series XIV. London, 1989. 720 p. 


\section{Subgenus Bivalvaria}

Section Aranella

$U$. blanchetii, A. DC.; $U$. costata, P. Taylor; $U$. fimbriata, Kunth; U. laciniata, A. St.-Hil. \& Girard; $\underline{U}$. longeciliata, A. DC.; $\underline{U}$. parthenopipes, P. Taylor; $\underline{U}$. purpureocaerulea, A. St.-Hil. \& Girard; $\underline{U}$. $\underline{\text { rostrata, }}$ A. Fleischm. \& Rivadavia; $\underline{U}$. sandwithii, P. Taylor; $\underline{U}$ simulans, Pilg.

\section{Section Australes}

$\underline{U}$. delicatula, Cheeseman; $\underline{U}$. lateriflora, $\mathrm{R}$. Br.; $\underline{U}$. simplex, $\mathrm{R} . \mathrm{Br}$.

Section Avesicarioides

U. rigida Benj.; U. tetraloba, P. Taylor.

Section Benjaminia

U. nana, A. St. Hil. \& Girard.

Section Calpidisca

U. arenaria, A. DC.; U. bisquamata, Schrank; $U$ firmula, Welw. ex Oliv.; $\underline{U}$. livida, E. Mey.; $\underline{U}$. microcalyx, P. Taylor; $\underline{U}$. odontosepala, Stapf; $U$. pentadactyla, P. Taylor; $U$. sandersonii, Oliv.; $U$. troupinii, P. Taylor; U. welwitschii, Oliv.

Section Enskide

U. chrysantha, R. Br., U. fulva F. Muell.

Section Lloydia

U. pubescens, Sm.

Section Minutae

U. simmonsii, Lowrie, Cowie \& Conran.

Section Nigrescentes

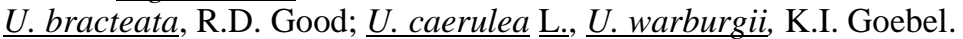

Section Oligocista

U. adpressa, Salzm. ex A. St.-Hil. \& Girard; U. albocaerulea, Dalzell, U. andongensis Welw. ex Hiern; U. arcuata, Wight; U. babui, S.R. Yadav, Sardesai \& S.P. Gaikwad; U. bifida L., U. bosminifera, Ostenf.; U. cecilii, P. Taylor; U. chiribiquitensis, A. Fernández; U. circumvoluta, P. Taylor; U. delphinioides, Thorel ex Pellegr.; U. erectiflora, A. St.-Hil. \& Girard; U. foveolata, Edgew.; U. graminifolia, Vahl; U. heterosepala, Benj.; U. involvens, Ridl.; U. jackii, J. Parn.; U. laxa, A. St.-Hil. \& Girard; U. lazulina, P. Taylor; U. letestui, P. Taylor; U. lloydii, Merl ex F.E. Lloyd; U. macrocheilos, P. Taylor; U. malabarica, Janarth. \& A.N. Henry; U. meyeri, Pilg.; U. micropetala, Sm.; U. odorata, Pellegr.; U. pierrei, Pellegr.; U. pobeguinii, Pellegr.; U. polygaloides, Edgew.; U. praeterita, P. Taylor; U. prehensilis, E. Mey.; U. recta, P. Taylor; U. reticulata, Sm.; U. scandens, Benj.; U. smithiana, Wight; $U$. spiralis, Sm.; U. subramanyamii, Janarth. \& A.N. Henry; U. tortilis, Welw. ex Oliv.; $U$. uliginosa, Vahl; $U$. vitellina Ridl.; U. wightiana, P. Taylor.

Section Phyllaria

$U$. brachiata, Oliv.; U. christopheri, P. Taylor; $U$. corynephora, P. Taylor; $U$. forrestii, P. Taylor; $U$. furcellata, Oliv.; $U$. garrettii, P. Taylor; $\underline{U}$. kumaonensis, Oliv.; $\underline{U}$. moniliformis, P. Taylor; $\underline{U}$. multicaulis, Oliv.; 
$\underline{U}$. pulchra, P. Taylor; U. salwinensis, Hand.-Mazz.; U. steenisii, P. Taylor; U. striatula, Sm.

Section Stomoisia

$\underline{U}$. cornuta, Michx.; $\underline{U}$. juncea, Vahl.

Subgenus Polypompholyx

Section Pleiochasia

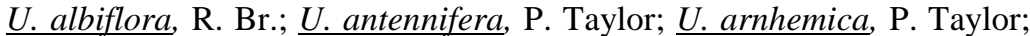
$\underline{U}$. beaugleholei, Gassin; $\underline{U}$. benthamii, P. Taylor; $\underline{U}$ capilliflora, F. Muell.;

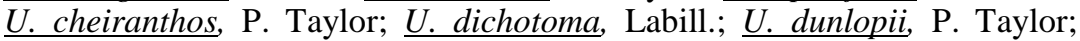

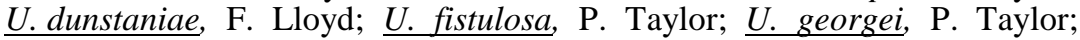
$U$. hamiltonii, F. Lloyd; U. helix, P. Taylor; U. holtzei, F. Muell.; U. inaequalis, A. DC.; U. kamienskii, F. Muell.; U. kenneallyi, P. Taylor; $\underline{U}$. kimberleyensis, C.A. Gardner; U. lasiocaulis, F. Muell.; U. leptorhyncha, O. Schwarz; U. menziesii, R.Br.; U. paulineae, Lowrie; $\underline{U}$. petertaylorii, Lowrie; $U$. quinquedentata, F. Muell. ex P. Taylor; $U$. rhododactylos, $\mathrm{P}$. Taylor; $U$. singeriana, F. Muell.; $U$. terrae-reginae, $\mathrm{P}$. Taylor; $U$.tridactyla, P. Taylor; $U$. triflora, P. Taylor; $U$. tubulata, F. Muell.; $\underline{U}$. uniflora, R. Br.; $\underline{U}$. violacea, $\mathrm{R} . \mathrm{Br}$; $\underline{U}$. volubilis, $\mathrm{R} . \mathrm{Br}$.

Section Polypompholyx

U. multifida, R. Br.; U. tenella, R. Br.

Section Tridentaria

U. westonii, P. Taylor.

Subgenus Utricularia

Section Avesicaria

U. neottioides, A.St. Hil \& Girard; U. oliveriana, Steyerm.

Section Candollea

U. podadena, P. Taylor.

Section Chelidon

U. mannii, Oliv.

Section Choristothecae

U. choristotheca, P. Taylor; U. determannii, P. Taylor.

Section Foliosa

$\underline{U}$. amethystina, Salzm. ex St. Hil. \& Gir.; $\underline{U}$. calycifida, Benj.; $U$. hintonii, P. Taylor; $U$. hispida, Lam.; $U$. huntii, P. Taylor; $\underline{U}$. longifolia,

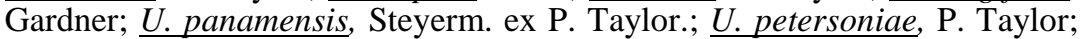
$\underline{U}$. praelonga, A. St.-Hil. \& Girard; $\underline{U}$. schultesii, A. Fernández; $\underline{U}$. tricolor

A. St.-Hil.; $\underline{U}$.tridentata, Sylvén.

Section Kamienskia

U. mangshanensis, G.W. Hu; U. peranomala, P. Taylor.

Section Lecticula

$\underline{U}$. resupinata, Greene ex Bigelow; $\underline{U}$. spruceana, Benth. ex Oliver.

Section Martinia

U. tenuissima, Tutin.

Section Meionula

$\underline{U}$ geoffrayi, Pellegr.; $\underline{U}$. hirta, Klein ex Link; $\underline{U}$. minutissima, Vahl; U. ramosissima, Wakabayashi. 
Section Mirabiles

U. heterochroma, Steyerm.; U. mirabilis, P. Taylor.

Section Nelipus

$\underline{U}$. biloba, R. Br.; U. leptoplectra, F. Muell.; $\underline{U}$. limosa, R. Br.

Section Oliveria

U. appendiculata, E.A. Bruce.

Section Orchidioides

$\underline{U}$. alpina, Jacq.; $\underline{U}$. asplundii, P. Taylor; $U$. buntingiana, P. Taylor; U. campbelliana, Oliv.; U. cornigera, Studnička; U. endresii, Rchb.;

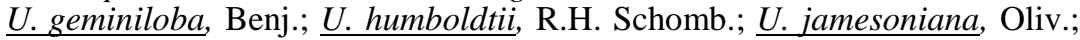
$U$. nelumbifolia, Gardner; $U$. nephrophylla, Benj.; $U$. praetermissa, P. Taylor; $U$. quelchii, N.E. Br.; $\underline{U}$. reniformis, A. St.-Hil.; $\underline{U}$. unifolia, Ruiz \& Pav.

Section Setiscapella

U. flaccida, A. DC.; U. nervosa, G. Weber ex Benj.; U. nigrescens, Sylvén; $U$. physoceras, P. Taylor; $U$. pusilla, Vahl; $U$. stanfieldii, P. Taylor; U. subulata L., U. trichophylla, Spruce ex Oliver; U. triloba, Benj.

Section Sprucea

U. viscosa, Spruce ex Oliv.

Section Steyermarkia

U. aureomaculata, Steyerm.; U. cochleata, C.P. Bove; $\underline{U}$. steyermarkii, P. Taylor.

Section Stylotheca

U. guyanensis, A. DC.

Section Utricularia

$U$. aurea, Lour.; $U$. australis, $\mathrm{R}$. Br.; $U$. benjaminiana, Oliv.; $\underline{U}$. biovularioides (Kuhlm.), P. Taylor; U. bremii, Heer ex Kölliker; U. breviscapa, Wright ex Griseb.; U. chiakiana, Komiya \& C. Shibata; $U$. cymbantha, Oliv.; $U$. dimorphantha, Makino; $U$. floridana, Nash; $\underline{U}$. foliosa L., $\underline{U}$. geminiscapa, Benj.; $\underline{U}$. gibba L., $\underline{U}$. hydrocarpa, Vahl; U. incisa (A. Rich.), Alain; $U$. inflata, Walter; $U$. inflexa, Forssk.; U. intermedia, Hayne; $U$. macrorhiza, Le Conte; U. minor L., U. muelleri, Kamiénski; $U$. naviculata, P. Taylor; $\underline{U}$. ochroleuca, R.W. Hartm.; U. olivacea, Wright ex Griseb.; U. perversa, P. Taylor; U. platensis, Speg.; $U$. poconensis, Fromm; U. punctata, Wall. ex A. DC.; U. radiata, Small;

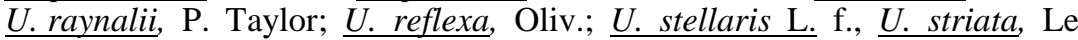
Conte ex Torr.; $\underline{U}$. stygia, G. Thor, $\underline{U}$. vulgaris L., $\underline{U}$. warmingii, Kamiénski.

Section Vesiculina

U. cucullata, A. St.-Hil. \& Girard; U. myriocista, A. St.-Hil. \& Girard; U. purpurea, Walter.

Представлені вісім видів колекції Ботанічного саду належать до

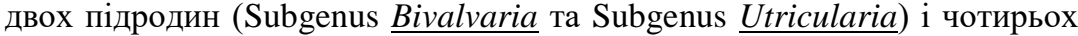
секцій:

Section Calpidisca - Utricularia livida, E. Mey.;

Section Oligocista - Utricularia prehensilis, E. Mey.;

Section $\underline{\text { Foliosa }}$ - Utricularia tricolor, A. St.-Hil.; 
Section Utricularia - U. australis, R. Br.; U. gibba L., U. intermedia, Hayne; U. minor L., $\underline{U}$. vulgaris L.

\section{ВИСНОВКИ}

Представлено рід Utricularia L. найбільший за кількістю видів серед усіх комахоїдних рослин. Це рідкісні та зникаючі рослини. Зростання в перезволожених грунтах, водоймах, болотах i «цистернах» рослин родини Bromeliaceae Juss. накладає відбиток на біоекологічні особливості рослин. Їхній життєвий цикл пов'язаний із лімнофазою, прибережною та болотною екофазою, які в умовах інтродукції штучно створено в засіках. Тип пасток - засмоктувальний. Життєва форма інтродукованих болотних та водного видів роду Utricularia L. плейстофіти та водні гемікриптофіти, улігінозофіти, стеноулігінозофіти, геліофіти, гідатофіти, утриуляреїди, ентомофіли, гідрохори. Більшість рослин роду вільно плавають або пускають підземні пагони (стеблового походження) у вологий мул. 3 морфологічного погляду інтродуковані в захищений грунт Ботанічного саду ім. акад. О.В. Фоміна види роду Utricularia, в умовах інтродукції, характеризуються цілковитою відсутністю кореневої системи, адаптаційною пластичністю та варіабельністю вегетативних органів. Пухирці рослин $є$ видовою ознакою. Опрацьований загальний світовий список роду й інтродукованих 8 видів у захищений i відкритий грунт Ботанічного саду. Залежно від екобіологічних особливостей рід налічує 233 види, які представлені водними - 78, терастральними - 145, епіфітно-літофітними - 45. Водні рослини складають $33,9 \%$, терастральні - 63\%, а літофітно-епіфітні - 19,5\% від загальної кількості видів. Серед них $є$ такі, що можуть перебувати у двох і навіть у трьох підгрупах водночас. Центр видового різноманіття роду Utricularia зосереджений у Південній Америці, де зростає найбільше представників. Інтродуковані види колекції Ботанічного саду належать до двох підродин і чотирьох секцій. Інтродукція роду можлива за створення оптимальних умов утримання з урахуванням екобіоморфологічних особливостей рослин посезонно. Наведено методи догляду та розмноження для водних і терастральних видів колекції.

\section{АНОТАЦІЯ}

Наведені результати дослідження екологічних і біоморфологічних особливостей представників роду Utricularia L. Досліджено систематику роду, видовий склад, секції, за якими представлений рід. Встановлено, що залежно від екобіологічних особливостей рід представлений водними, терастральними, епіфітно-літофітними видами. Найбільшу кількість становлять терастральні види рослин. Серед них $\epsilon$ такі, що можуть перебувати у двох і навіть трьох підгрупах одночасно. Розглянуто ареал поширення, будову ловильного апарату, умови інтродукції. Запропоновані методи догляду та розмноження. 


\section{ЛIТЕРАТУРА}

1. Національна доповідь України про збереження біологічного різноманіття / уклад. : В. Давидок та ін. ; за ред. Я. Мовчана, Ю. ШелягСосонко. Київ : Мінекобезпеки України, 1997. 202.

2. Андрієнко Т. Комахоїдні рослини України / за ред. В. Протопопової. Київ : Альтерпрес, 2010. 80 с.

3. Земскова Е. Семейство Пузырчатковые (Lentibulariacea). Жизнь растений. Т. 5., Ч. 2. Москва : Просвещение, 1981. С. 440-442.

4. Taylor Peter. The genus Utricularia : A taxonomic monograph. Kew Bulletin Additional. Series XIV. London, 1989. 720 p.

5. Кернер фон Марилаун А. Жизнь растений. Санкт-Петербург : Книгоиздательское товарищество «Просвещение», 1899, Т. 1. C. $115-145$.

6. Goebel W. Insektivores. Pflanzenbiologische Schilderungen. II-ter Teil. Marburg : N.C. Elwert'sche Verlagsbuchhandlung, 1891. S. 51-174.

7. Wagner A. Die fleischiressenden Pflanzen. Aus Natur- und Geisteswelt. 344. Leipzig, 1911. 128 p.

8. URL: http://en.wikipedia.org/wiki/ Utricularia.

9. URL: http://www.omnisterra.com/bot/cp_home.cgi.

10. Brummitt R. Vascular plant families and genera. London : R.B.G. Kew, 1992. 732 p. $804 \mathrm{p}$.

11. Brummitt R. Autohors of Plant Names. London : R.B.G. Kew, 1992. $247 \mathrm{c}$.

12. Тахтаджян А. Флористические области Земли. Ленинград, 1978.

13. Hejný S. Okologische charakteristik der Wasser und Sumpflanzen in den slowakischen Tiefebenen. Bratislava: Vyd-vo SAV, 1960. 487 S.

14. Холодний М. Комахоїдні рослини. Київ : Видав-во Академії наук УРСР, 1938. $108 \mathrm{c}$.

15. Fenner C. Beiträge zur Kenntnis der Anatomie, Entwicklungsgeschichte und Biologie der Laubblätter und Drüsen einiger Insektivoren. Allg. Bot. Z. 93. 1904. S. 335-434.

16. Цимбалюк 3., Мосякін С., Безусько Л. Порівняльноморфологічна характеристика пилкових зерен видів Pinguicula L. та Utricularia L. флори України. Украӥнський ботанічний журнал. 2007. T. 65. № 4. C. 520-534.

17. Дідух А., Мазур Т., Дідух М. Біоморфологічні особливості роду Utricularia L. у Ботанічному саду ім. акад. О.В Фоміна. Вісник Київського університету. Інтродукиія та збереження рослинного різноманіття. 2016. Вип. 1 (34) 16. С. 14-18.

18. Дідух А., Мазур Т., Дідух М. Систематична характеристика колекції комахоїдних рослин Ботанічного саду ім. акад. О.В. Фоміна (родина Lentibulariaceae Rich., рід Utricularia L.). Природничий альманах. Біологічні науки : збірник наукових праць. Вип. 23. Херсон, 2016. C. 63-75. 
19. Дідух А., Мазур Т., Дідух М. Видовий склад роду Utricularia L. та його екобіоморфологічні особливості (родина Lentibulariaceae Rich.). Природничий альманах. Біологічні науки : збірник наукових праць. Вип. 23. Херсон, 2016. С. 43-62.

20. Utricularia australis R. Br. (Lentibulariaceae) - новий вид для флори Прикарпаття / I. Данилик та ін. Украӥнський ботанічний журнал. 2007. T. 64. № 2. С. 242-246.

21. Darwin Ch. Insectivorous plants. $1875.361 \mathrm{p}$.

22. Withycombe C. On the function of the biadders in Utricularia vulgaris. The Journal of the Linnean Society. Botany. 1924. Bot. V. 46. P. 401.

23. Hegner R. The interrelations of Protozoa and the utricles of Utricularia. Biology Bulletin. 1926. V. 50. P. 239-270.

24. Адова А. К вопросу о ферментах Utricularia vulgaris. Журнал Русского ботанического общества. 1924. Т. 9. С. 189.

25. Stutzer M. Zur Biologie der Utricuiaria vulgaris. Areh. Hydrobiol. 1926. Bd. 17. S. 730.

\section{Information about authors:}

Didukh A. Ya.,

Candidate of Biological Sciences, Junior Researcher

ESC "Institute of Biology and Medicine" Taras Shevchenko National University of Kyiv 64/13, Volodymyrska str., Kyiv, 01033, Ukraine

Nuzhyna N. V.,

Candidate of Biological Sciences, Senior Researcher

ESC "Institute of Biology and Medicine"

Taras Shevchenko National University of Kyiv 64/13, Volodymyrska str., Kyiv, 01033, Ukraine

Mazur T. P.,

Candidate of Biological Sciences, Senior Researcher, Leading Biologist O. V. Fomin Botanical Garden of ESC "Institute of Biology and Medicine" Taras Shevchenko National University of Kyiv 1, Simona Petlyury str., Kyiv, 01032, Ukraine 